Historic, Archive Document

Do not assume content reflects current scientific knowledge, policies, or practices. 

Hugo Kind

Phone 440

Date

State here whether you want shipment to

be made by Mail, Express or Freight

Name

When Ship

Street Address or Box No.

Post Office

County

R. D. Route

State

If different from Post Office give

name of Ixpress or Freight Office

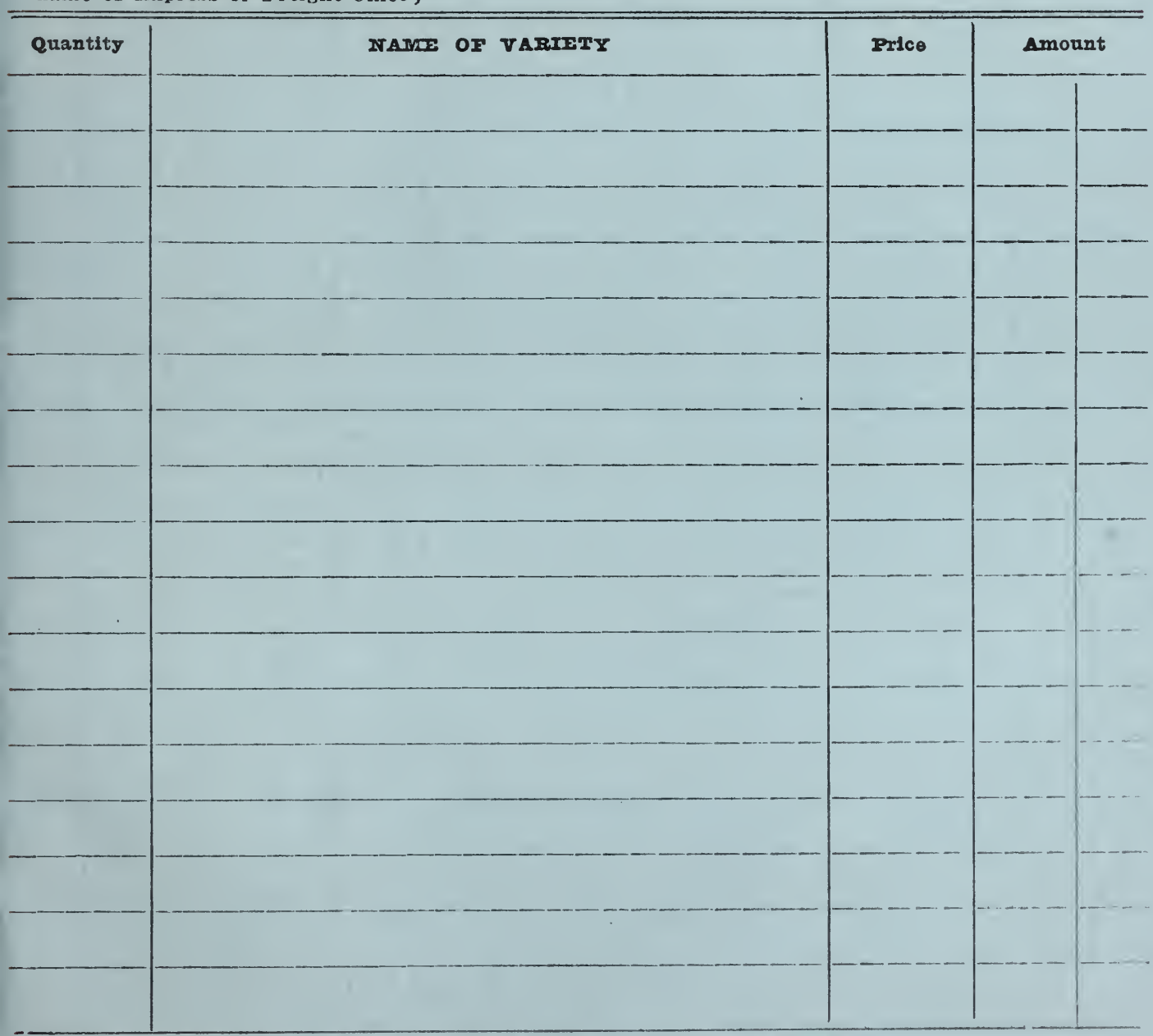


SHADY LAWN NURSERIES : Hugo Kind : HAMMONTON, N. J.

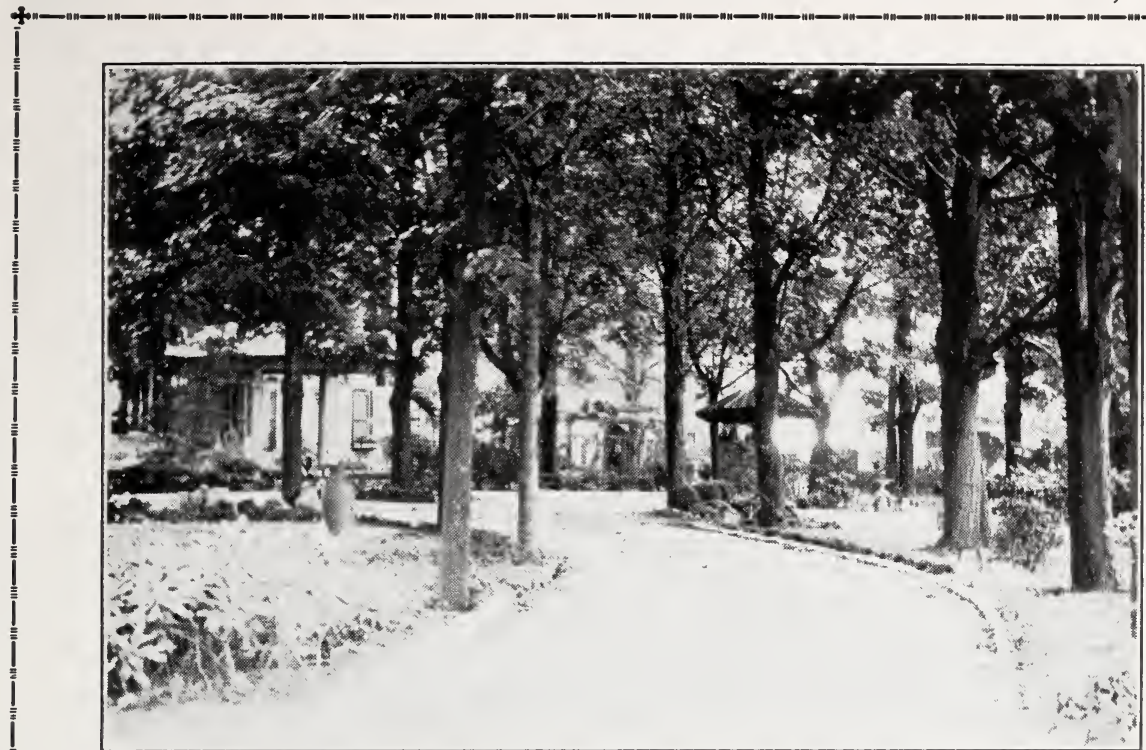

North Entrance to Shady Iawn.

TO OUR CUSTOMERS :

Wenn Sie wollen koenen Sie Ihre Bestellungen in Deutsch schreiben.

On teux remettre les ordres en francais.

Our foremost thought has been Quality, and Dahlias has been a life-long study with us and is our Specialty.

It has not been our policy to send our list broadcast, but to cater to those who appreciate Quality and Service.

Personal attention to all orders, large or small.

Prompt shipments.

Immediate reply to all correspondence.

Advice cheerfully given.

Hammonton, "The Hub of South Jersey," is located half way between Philadelphia and Atlantic City on both the Pennsylvania Railroad and the Reading Railroad. There are many express trains direct to both points as well as direct service to New York. We extend to you a cordial welcome to a visit any time of the year. Time tables will be sent on request and it will be a pleasure to meet you at the station. Our Nursery is just two and a half miles from the depot.

\section{TO MOTORISTS}

The extensive "White Horse Pike," a concrete road in direct line from Philadelphia to Atlantic City will bring you within one half mile of our place. Ask any traffic officer or resident when reaching Hammonton and they will gladly direct you to our Nursery.

\section{ROUTE 39-TRENTON TO ATLANTIC CITY Upon Which We Are Located}




\section{Please Read Before Ordering}

\section{BUSINESS TERMS}

Cash Only. A special 5 per cent discount on all orders on bulbs (packing free) of $\$ 10.00$ and over. No discount on C. O. D. orders. As to my responsibility I refer you to Dunns or Bradstreets Mercantile Agency. To the Peoples Bank of Hammonton, N. J., Clayton Title \& Trust Co., Clayton, N. J.

Though it is seldom we fail to complete accepted orders we cannot be held responsible should we fail to do so.

This list cancels all previous lists and quotations.

Shipping Instructions: Always state by what method you want goods forwarded, otherwise I will use my best judgment.

Claims must be made within 5 days after receipt of goods. All goods travel at purchaser's risk.

Non-Warrant: I endeavor to send out the best quality only, true to name, but I cannot guarantee results. If customers do not accept goods on the above conditions, they can be returned to me within 10 days.

Parcel Post: If you wish parcel post shipment remit sufficent to cover charges. We will return any overamount that may be sent. Or extra bulbs if so desired.

Packing: Packing will be charged at cost unless cash with order. For the larger bulb orders we pack in uniform airtight sugar size barrels, which are charged at 65 cents each. No orders accepted under $\$ 1.00$.

Please Order Early and avoid possible disappointment. All orders are booked subject to previous sales.

Early Orders can be placed for later shipping, providing 25 per cent of its value is remitted when ordering. We cannot hold stock later than June 1 .

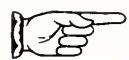

In the event that we are sold out of certain varieties, we will substitute to our best judgment, unless ordered not to do so.

\section{OUR POLICY}

We do not sell to Jobbers or Department stores.

It is our aim that we supply those that grow direct for the purpose of growing plants or flowers to sell, or dealers that supply the trade.

If you are not thoroughly acquainted with Dahlias best suited for your purpose, write us and we shall be glad to help you to the best of our knowledge. 


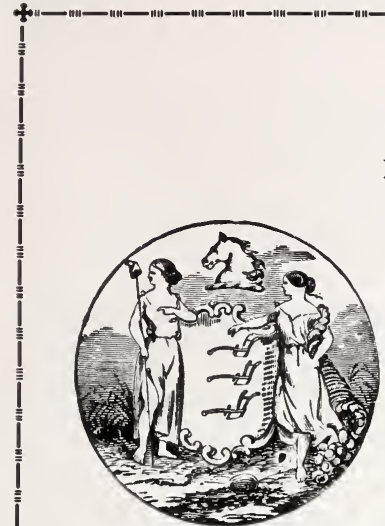

\section{STATE OF NEW JERSEY ALVA AGEE, Secretary}

Bureau of Statistics and Inspection HARRY B. WEISS, Chief No. 280

Trenton, N. J., September 1, 1930

This is to certify that we have this 8th day of July, 1930 , in accordance with the provisions of Chapter 268, Laws of 1916 State of New Jersey, inspected or caused to be inspected by a duly appointed Inspector the general nursery stock growing in the Shady Lawn Nurseries of Hugo Kind, proprietor, at Hammonton, in Atlantic County, New Jersey, and have found the same apparently free from San Jose and other dangerously destructive insect pests.

This certificate expires June 1, 1931, and covers stock actually in the nurseries when examined.

WM. H. MARTIN,

State Plant Pathologist.

THOMAS J. HEADLEE, State Entomologist.

RALPH B. LOTT, Chief Inspector.

\section{FROM NURSERY CERTIFIED BELOW \\ VIRGINIA DEPARTMENT OF AGRICULTURE AND IMMIGRATION}

Official Tag No. 1474

Richmond, Va., November 23, 1930.

This is to certify that the certificate of a duly accredited inspector has been filed in this office stating that the premises of Shady Lawn Nursery, Hugo Kind, Hammonton, New Jersey, were examined season of 1930 and that the above mentioned certificate conforms to laws and regulations in force in this State.

This tag expires August 31, 1930. Issued on certificate of

T. J. HEADLEE,

G. T. FRENCH,

State Entomologist.

State Entomologist and Plant Pathologist.

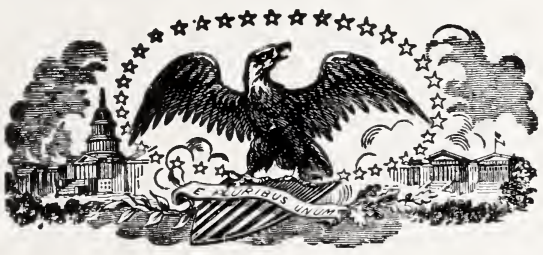

Note-U. S. Federal Inspection

It is our custom to have Federal Inspectors, during shipping season, look over and carefully inspect our stock daily. All shipments undergo a rigid test. All stock so passed is labeled with the U. S. Department of Quarantine certificate.

SPECIAL RASPBERRY CERTIFICATE No. 3

\section{Trenton, N. J., 1930.}

This is to certify that the raspberry plants, roots or tips offered for sale by Hugo Kind of Hammonton, in Atlantic County, New Jersey, have been inspected in the field and found practically free from mosaic, leaf curl, rosette and similar diseases.

EDGAR G. REX, Chief Inspector. 
SHADY LAWN NURSERIES : Hugo KIND : HAMMONTON, N. J.

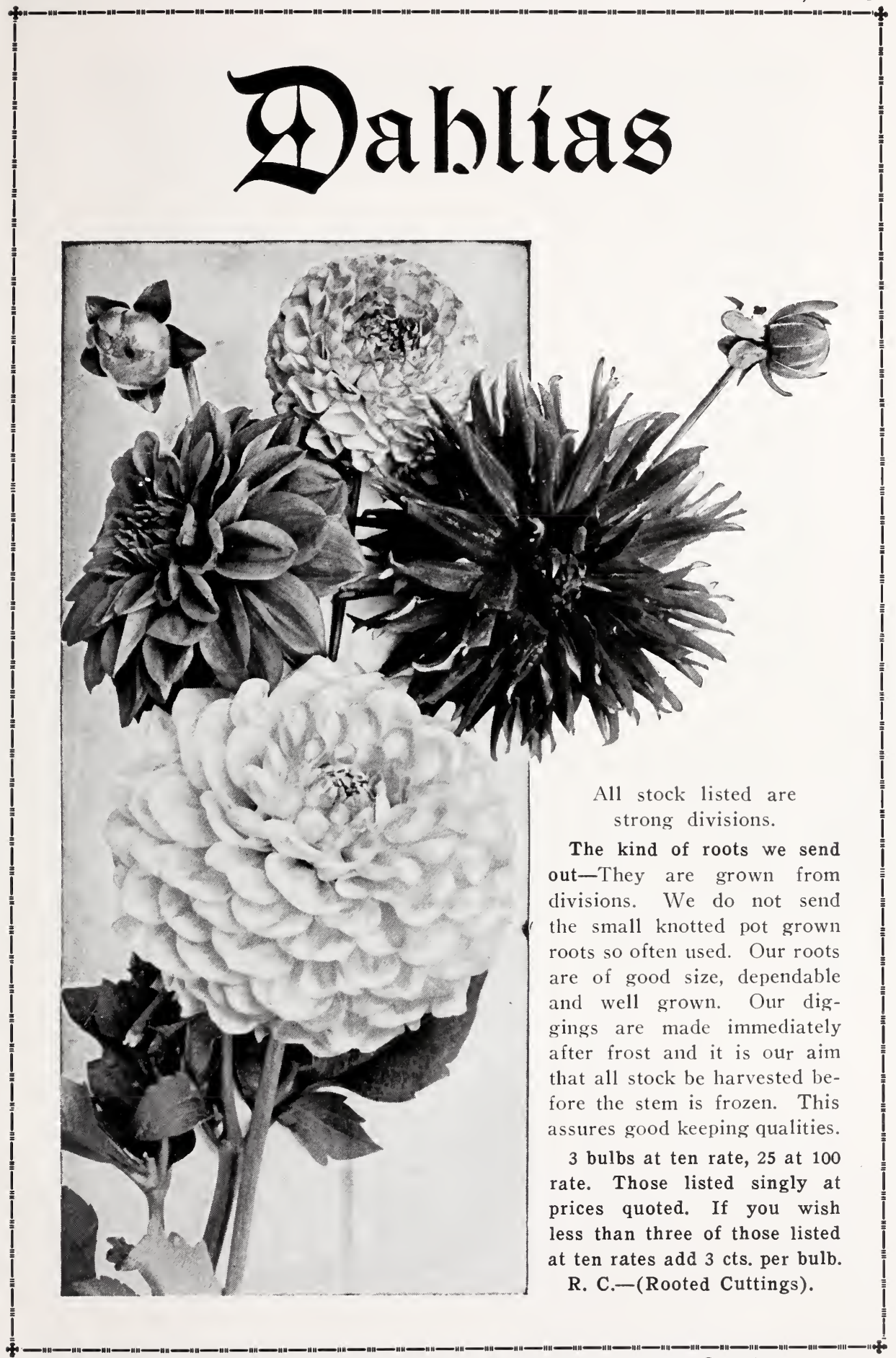

SHADY LAWN NURSERIES : Hugo KIND : HAMMONTON, N. J. 
SHADY LAWN NURSERIES : HUgo KIND : HAMMONTON, N. J.

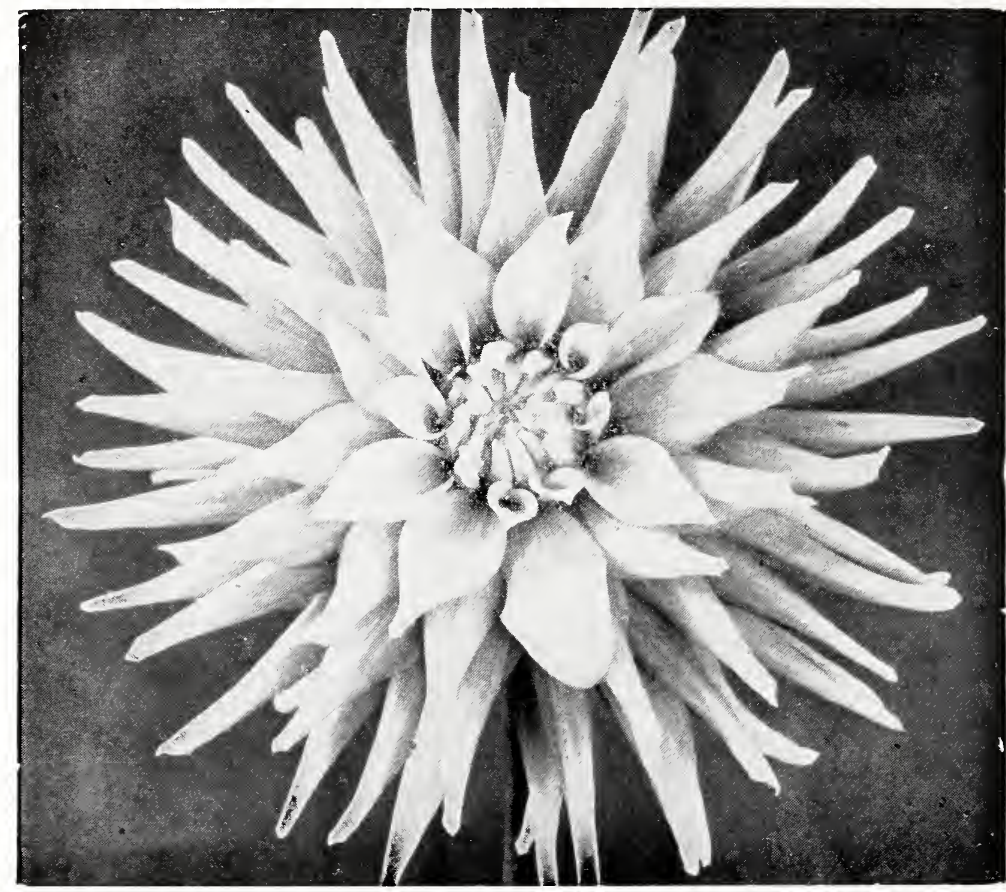

sunset criow.

\section{Cactus and Hybrid Cactus}

Each. 10.100.

Ambassador. Yellow buff, shaded apricot flower extremely large. See R. C._._._._._._._._.

Arduery Davenport. A white Dahlia of good form--

$3.00 \quad 25.00$

Attraction. Silvery Pink

2.00

$1.50 \quad 14.00$

Betty Austin. A Hybrid that is in a class by itself. The flowers are full to the center up to frost. Color, yellow at base of petal, blending to rosy carmine and rose, yellow at tips, reflex, rose....--

Bianca. Lavender. Not very good as a cut flower_

Break O'Day. H. C. A giant flowered Dahlia that should be in every collection. Its immense size is relieved by a beautiful irregular formation and its soft color. A delicate clear sulphur white at the tips. The petals are of great substance, illuminated by a satiny sheen, giving the flowers a waxy appearance. A strong vigorous grower and free bloomer with long erect stems. 
Each. 10.100.

Candeur. White, long stems, fine for cutting-------

$1.50 \quad 14.00$

Cigarette. Yellow, red and white all in one flower. Oftimes comes varied. No two flowers alike. Very free and fine

Countess of Lonsdale. There is no bronze dahlia today that has superseded this variety in all points. "The Dahlia for the million" as one seed house stated_-

Crepuscle. Yellow shaded orange________-__-_ 2.00

Daddy Butler. Pink of a rose color shade with suggestions of white; stems good; flowers last after cut

Edna Ferber. One of the leading hybrid cactus of the season. Large flower on strong stiff stems. Coral and shadings of gold. Always seen at shows

Edith Carter. Bright yellow heavily tipped carmine.

Electric. Yellow splashed red.

Elegant. Similar to Woden in habit and flower formation, but has better color and more refined appearance

Emma Marie. H. C. Pink. White center, stems perfect; a fine exhibition flower

Etendard de Lyon (Hybrid Cactus). Rich carmine rose. One of the best standard varieties.

Fascination. Red, tipped white

Flora. Jvory white

Francis White. White, long stems

F. W. Fellows. Flowers of immense size. Composed of numerous long narrow incurved petals of a lively orange scarlet. This is one of the largest and finest Autumn shade varieties. Should be in every collection

Gallard. Bright buff, fine

Gay Paree. Golden bronze with a faint suffusion of nasturtium red

Gertrude. Red base. Striped white flowers; large--

Gladys Bates (Boston). Tan reverse rose. A cut

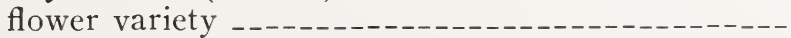

Golden West. Golden shrimp___-_-_._-_._-_-_

Good Samaritan. White free. A fine cut flower----

Helen Durnbaugh. Silvery pink. 
SHADY LAWN NURSERIES : Hugo KIND : HAMMONTON, N. J.

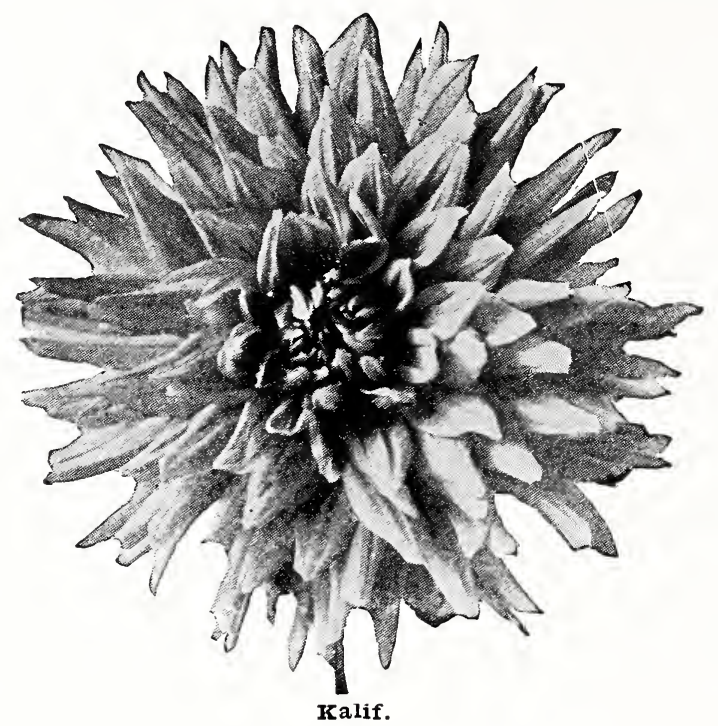

Each. 10.100.

Islam Patrol (Giant Hybrid Cactus) (Davis). A georgeously colored flower; a velvety crimsonscarlet tipped and flushed with pure gold. It is very early and holds its perfect shape to the end of the season; one of our most brilliantly-colored varieties

Jean Chazot or Gay Paree. Described under later name

J. H. Jackson. Dark maroon almost black

Jacks Discovery. (Same as Mrs. C. H. Breck)..---

Kalif. Vivid turkey red, good stems. One of the best.

King Solomon. Deep orange. Large and fine

Lady Swathling. Pink ________________ 2.00

La Favorita (H. C.). Brick orange__________- 1.50

Lawine. White with slight suggestion of lavender. $\quad 1.50$

Leo XII. Sulphur yellow_____. 1.50

Lolita Velasco (Bessie Boston). Pure white large, good stem.

Marathon. Rich purple____________- 2.00

Marguerite Bouchon. Pink tipped white-_._-_-_-_- 1.50

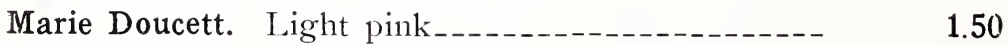

Mariposa (H. C.). Pink suffused violet. See R. C.-- 2.50 
SHADY LAWN NURSERIES : Hugo KIND : HAMMONTON, N. J.

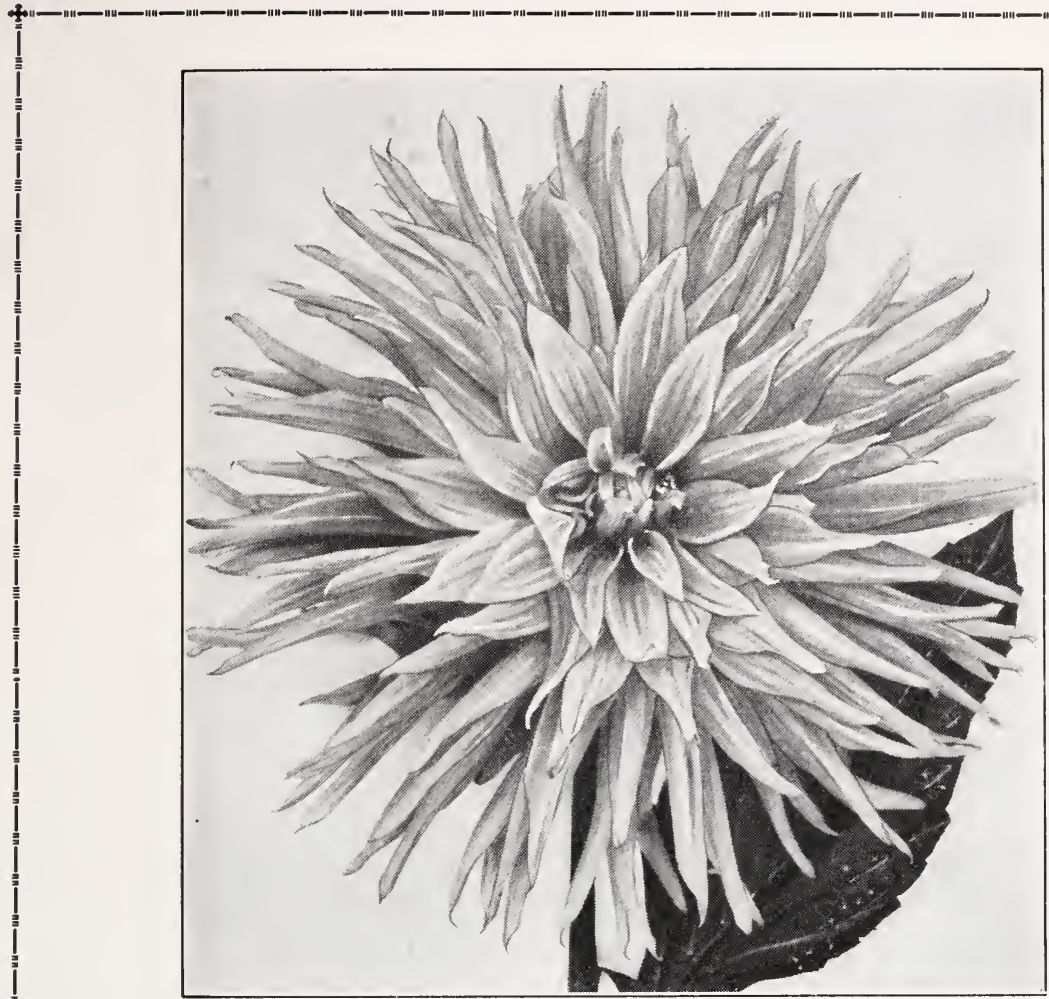

Gay Paree.

Each. 10.100.

Majorie Castleton. Soft pink, very fine

Mary Dorr. One of the most beautiful of all cuctus dahlias and the best of the deep pink and white type

Mme. Eschanauer. Light lavender. A good flower for funeral designs.

Mrs. C. H. Breck. One of the most effective varieties for all purposes. Color soft yellow, suffused and tipped carmine, bright and effective. The plant is a strong, vigorous grower of dwarf branching habit and an early, profuse and continuous bloomer. The flowers are large and borne on stiff erect stems. It is a hybrid decorative-_--

Mrs. Edna Spencer. An exceptionally fine variety for all purposes, large size, fine form and above all, a free bloomer, on long erect stems. Color silvery lilac, shading to bright orchid pink 
Sophy Morey. Cactus of most wonderful coloring. able sort for cutting. A color that is rarely found in cut flower sorts. Do not fail to have at least a row of this variety for your trade

Springfield. Red overlaid salmon___-_._-_-_-_-_-

Sunset Glow. It is larger than Red Cross and better color; it is always perfect in form and will produce several times as many flowers. The color is yellow at base of petal, outer part overlaid flame scarlet, tipped yellow. The plant is one of the very first to bloom, of medium height, 3 to 4 feet and branching habit. It is an extremely profuse bloomer and every flower is perfect. As it is larger and better colored than Red Cross, it is not only the best of this type for garden and commercial cut flowers, but a splendid exhibition bloom_-_-_-

Sunshine. Red with yellow shadings, fine cut flower

Sweet Briar. Pink, fine for cutting-_-_-_-_-

Thais. White shaded lilac. Excellent for spray.----

Tom Lundy. H. C. Valvet red. A California favorite

10.

100.

Theodore Roosevelt (H. C.). A new and very attractive dahlia that we listed for the first time last season. The flowers which are borne on long stiff stems are a beautiful shade of yellow. Each petal is finely curved and reflects to the stem as the flowers fully expand. Different than most other dahlias in this respect. It is of a hybrid cactus variety. 8 to 9 in. across. Keeps a long while after cutting.

Valiant. Crimson

Wasco Beauty (Peoney Cactus). Large varigated flower composed of shaggy incurved petals of a pretty Geshia color-_._-_-_-_-_._-

Washington City. Snow white, of beautiful form and borne on long stems. The flowers are of enormous size

Wodan. Old go'd

Yellow King. One of the largest of all cactus dahlias, being of gigantic size and of the finest new cactus. Color light yellow, tinting to cream at the tips, giving it a most pleasing affect. The immense flowers are borne on long, stiff but slender stems. Very late 
SHADY LAWN NURSERIES : Hugo Kind : HAMMONTON, N. J.

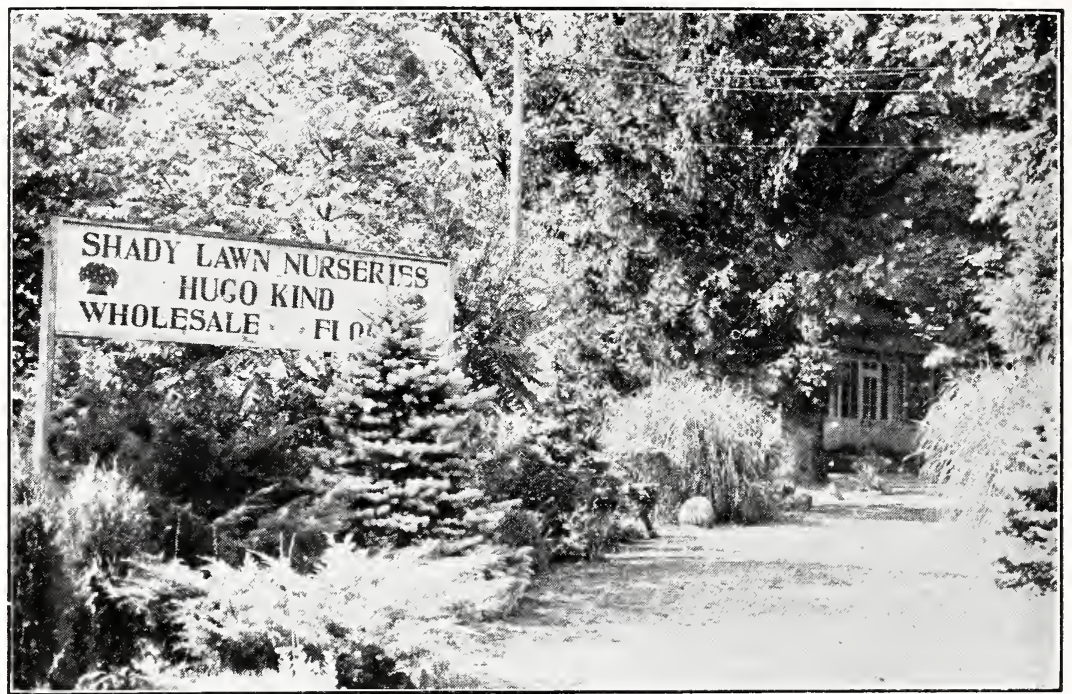

South Entrance at Shady Iawn Nurseries.

As a Charter Member of the American Dahlia Society I invite you to join this grand organization.

If we should ship you by mistake,

Or in your bill some error make,

From irritation you'd be free

If I knew you and you knew me.

Or when the checks don't come on time,

And customers send us nary a line,

We'd wait without anxiety

If I knew you and you knew me.

Then let no doubting thoughts abide

Of firm good faith on either side;

Confidence to each other give,--

Living ourselves, let others live.

But any time you come this way,

That you will call we hope and pray:

Then face to face we each shall see,

And I'll know you and you'll know me.

CONSULT PAGE 34 FOR ROOTED CUTTINGS

SHADY LAWN NURSERIES : Hugo KIND : HAMMONTON, N. J. 
SHADY LAWN NURSERIES : Hugo Kind : HAMMONTON, N. J.

\section{Decorative and Hybrid Varieties}

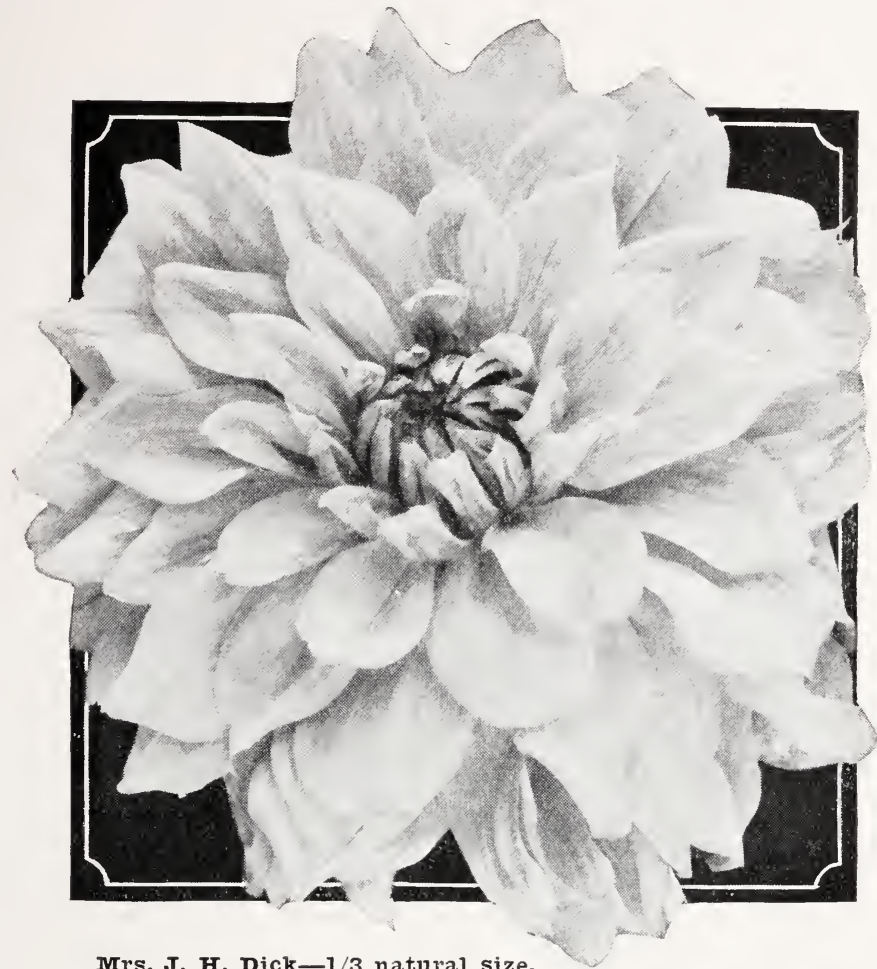

Mrs. J. H. Dick-1/3 natural size.

Each. $10 . \quad 100$.

Adda Patterson (H. C.). White. Large and fine.

Worth trying as an exhibition flower......-.-.

Adeline Winter. Tall, red, long stems. Good for background effect.

Admiral Dewey (Peony Dec.). Giant fluffy flower, bronzy yellow with red suffusion_._._._._._. 2.00

Aida. Giant deep maroon. An exceptionally fine dahlia

Alice Witte. A free white. Similar to Princess Juliana.

Albatross. A very large white on long stems.

Pendant neck

Amityville. Large light silver pink; extra fine. 
SHADY LAWN NURSERIES : Hugo Kind : HAMMONTON, N. J.

\section{DECORATIVE AND HYBRID VARIETIES-Continued}

Each. 10.100.

Amarillo Grande. Another large dahlia in the bronze colorings. So many Dahlias are classed in the bronze shades that it is considered best to give them a trial as they are truly all different.

Amun Ra (Seal). An immense decorative of coppery bronze; the stems are long and stiff and the flowers keep splendidly when cut

Amulet. Large and fine. Red____________-_ 1.25

Arbutus. Large fine decorative of the Arbutus coloring.

Aurora "B." Dark purple small white collarette like, petals intermingled. Very pretty_-_-_-_-_-_-

Autumn King. Bronze; good cut flower sort. See cut. Aurore. One of the most attractive dahlias in our 1.2510 .00 collection. Apricot with lovely shadings of peach and red pink. Just a marvelous color very hard to describe

Avalon. If we had to name this sort we would call it Jersey's Yellow, as all the best Dahlias appear with the prefix "Jersey." Chrome yellow. Stems equal to Jersey Beauty. Flowers immense. Ideal in every way. By no means fail to grow this marvelous yellow. See rooted cuttings_._._._._._._.

Ayesha. Light yellow, long stems_-_-_-_-_-_-_-_-

Azalea. Large yellow, shaded salmon, very good. Large

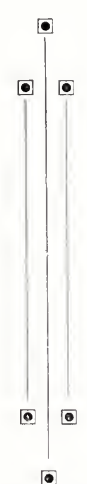

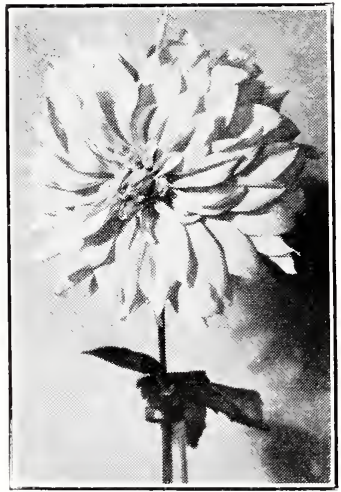

Eva Quadling. 1/6 natural size.
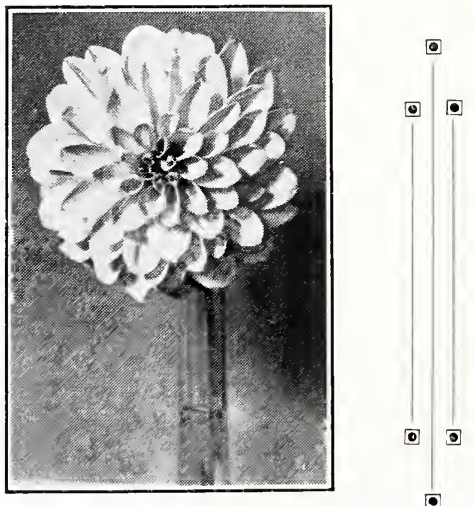


\section{DECORATIVE AND HYBRID VARIETIES-Continued}

Alexander Waldie. An attractive fawn color

Each. 10.

100.

Barbara Redfern. We have in this dahlia a forerun2.5018 .00 ner in the bronze shades. The immense flowers are held on long stiff stems. Must be seen to be appreciated. You should not fail to have this variety in your collection. See R. C. List

Barbara Wear. Of all the lavender shades we have here a forerunner. Our prediction is that this variety will supersede all in this color. R. C. only.

Bashful Giant. A large Dahlia in red and yellow. Very pretty

Bessie Boston. Cardinal red, finely cut petals, a beauty

IBob Pleuse. An incurved hybrid cactus, deep crimson with the end of every petal on every flower for about half the length shading to a white; when ever one sres this one. sale made; good stems, free bloomer. See R. C..._._.

Bonnie Brae. Cream shaded blush pink, very large_-

Break O'Day. Listed under cactus

Butterfly. See Fantasie. Known also as Mme. Butterfly

Calvin Coolidge. One of our leading prize winners. Red and white.

California Gold. (Described under Paul Michael).

Cambria. Giant rose pink lighter in center. One of the best of the English dahlias. Always a prize winner

Carmencita. A var.egation of red and vellow. Semi dwarf

Carmen Sylvia. Silvery pink

Casper Ware. Lavender pink of fine form

Catherine Wilcox. White tipped red.

Champagne. In plain words "Champagne color" if you have not forgotten the good old days. Stems are long and flowers solid 


\section{DECORATIVE AND HYBRID VARIETIES-Continued}

Each. 10.100.

Charles Stratton. Of all our Dahlias in the bronze colors I think this a prize wirner, in size it is enormous. The flowers seem endless as to the size that may be attained. Color very difficult to describe. A bronzey base intermingled with yellow. The petals curve most beautifully, giving this Dahlia a wonderful effect. Flowers produced on stems of a yard in length

Charm. Bronze.

City of Trenton. Rich tangerine. Reverse strawberry. R. C. only

Clare Kulp. Red, slightly intermingled with white. A large, perfect flower produced on very long, stiff stems. A cut flower of fine quality_._._._._...-

Dakota. One of Judge Marean's introductions producing very large exhibition flowers of good form on good stout stems, color a deep tone of rich coralred with coppery suffusion; a good decorative garden variety

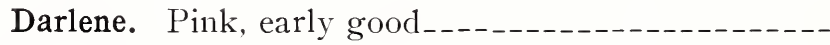

Dr. Tevis. Salmon rose, very large and a fine cut flower

Dorothy Robinson. A large bronze Dahlia of good form and habit. Long stems. A good keeper and one you should not miss. Said to do best along coast sections

Dusky Princess. Dark velvety background with lighter veins in petals

Earl Williams. Red, striped, white. Identical to Nobilis. Not a free bloomer._._._._._._._._._.

Eastern Star. Golden yellow with a bronze suffusion. Flowers are borne on long stiff stems. Used as a cut flower. See R. C.

Edith Wooster. Beautiful tea rose blend of red and yellow suffusion.

Elkridge. Bronze, large

Ella Rankin. Rosy carmine. Very pretty_._._._-_-_

Eldorado. Immense vivid gold_ 
DECORATIVE AND HYBRID VARIETIES-Continued

Elinor Vandeveer. Rose pink. See R. C._-_-_-_- 3.00

Elite Glory. Considered the extremity in size of the Dahlia world. Red. Stiff stems. Not a free flowering Dahlia which cannot be expected for flowers twelve inches across. Roots of this Dahlia are scarce

Eva Quadling. New. The most popular red as a commercial Dahlia in our selection

$\begin{array}{lll}1.50 & 9.00 \quad 80.00\end{array}$

Fantasie (Kreist). Bronze with violet reverse. Medium size flower.

Faith Gariboldi. A giant. Deep rose

Faith Slocombe. Old Gold, overlaid bronze and tinted red.

Fort Monmouth (H. C.). Rich carmine. A monster. See R. C.

Frank Walker. Early pink

Frau H. Scheiff. Golden bronze. Very attractive and and beautiful

Fordhook Avalanche. White. Good

General Custer (Peoney Dec.). Combination of yellow, white and coral red.

Gladys Serwood. White. Very large. Fine

Glory of Argonne. Delicate violet, rose, shading to white at center

Glory of New Haven. Clear lavender pink, distinctly veined deeper lavender. Very large and free. Useful for exhibition or cut flowers

Grand Duke Alexis. Frilled white

Grenadier. Magenta and white

Grizzly. A rich deep dark red. The plant is a vigorous grower and the large, stately blooms are freely produced on extra stout stems._._._._-_.-.

Halvella. Mallow Pink

Harvard. Large crimson red. A first-class dahlia in every respect._._.

Helen May Ranken. A pretty dahlia of a lilac rose.

Helen Ware. A very pretty lavender pink. Large and fine 
DECORATIVE AND HYBRID VARIETIES-Continued

Each. 10.100.

Henry Maier. Yellow suffused amber

1.00

8.00

Henry F. Michell. Fine red_______._. 1.00

Hocksai. Red and yellow, a beauty

$2.00 \quad 18.00$

Hope Moddle. Dark buff with yellow base. Exceptionally good for cutting and for autumn shade decoration

Hortulanus Fiet. Rich salmon pink; solt_.........

Hortulanus Witte. White, free-_._-_.-_-

$3.00 \quad 25.00$

2.00

Insulinde. Rich golden bronze, once a beauty_-_-_-

$2.50 \quad 20.00$

Isabel Streat. The flowers are large and are produced on long cane stiff stems. Red and yellow shades. Good

$3.00 \quad 25.00$

Islam Patrol (H. Cactus). Red and gold. Extremely in demand as a cut flower. Listed also under Cactus

Jack Rose. Jack rose red, still one of the best_...-.Jane Selby. Delicate mauve pink. Still one of the best California dahlias

Jane Cowl. Similar to that of Insulinde. Upright flower. Very large. Golden bronze. A shade darker than Insulinde. See R. C. list_._._._....-

Jane Hall. Yellow. Good Stems

Jean Kerr. Fine white

$1.50 \quad 14.00$

Jersey Beauty. Hubbard wrote: "When a man builds a better house or makes a better mouse trap than his neighbor the world will make a beaten path to his door." Jersey Beauty has its beaten path to its door. It needs not further introduction

Jersey's Beacon (Wait). Chinese scarlet. Flowers extra large on best of stems....................

Jersey's Gem (Wait). Lavender pink. Good_.....Jersey's Sovereign. A mighty fine apricot and fawn. Long stems and one of those you should try out for exhibition. R. C. only

Jersey's Ideal. Lavender. Flower large. Long stems.

John Merritt. A fine white. Free and a cut flower variety

J. L. Childs. Yellow, overlaid red 
DECORATIVE AND HYBRID VARIETIES-Continued

Each. 10.

100.

Jessie Prescott. Orange red.

3.00

Jonkheer Boreel. Soft yellow, shading to golden amber. Large, splendid form on long, stiff stems. Exhibition and cut flowers

Judge Marean. A striking shade of old rose. Soft_4.00

Judge Parker. Bronze. Large and fine_._-_._._-_-

Kemp's Violet Wonder. A prize wimner among the violet shades. R. C.

Kentucky (Castlewood). Claimed by Castlewood Dahlia Gardens to be equal to that of Jersey Beauty in habits and form, but of a bronze form

Kiffin Rockwell. Buff. Flowers tipped white, very beautiful, long stems. Attractive___-_-_-_-_-_-_-

$2.00 \quad 18.00$

King of Commerce. A fine bronze effect. Long stems.

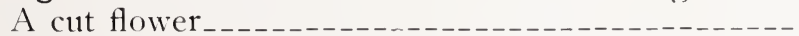

King Albert (Dec. Peony). A large magenta of attractive colorings

Kittie Dunlap. Lavender. It flowers early and continues perfect throughout the season. Blooms large and fine. A good cut flower

La Mascotte. Entirely distinct in formation and coloring. The face of the petals is silvery pink while the reverse is reddish violet, the petals being quilled on first opening, the two-toned effect produced is very novel and pleasing. The flowers are of medium size and are produced in great profusion

a Travatore. A red of good form. Worth a trial

Latonia. Yellow, overlaid old rose____________ 1.50

Laura Entriken. Rose pink

Leo Niessen. Of all the cut flower Dahlias of today there is positively none that has superceded this Dahlia in this color. A brilliant red. Stems very long. Keeping qualities unsurpassed_._._._._.-

Le Grande Manitou. Lilac, penciled crimson__-_._._-

Liberty Bell. Yellow and old rose. Pendent neck--

Lillian Baldwin. Magenta rose. Flowers large and fine. Flower inclined to face slightly downward. R. C. only 


\section{DECORATIVE AND HYBRID VARIETIES-Continued}

L. Kramer Peacock. Pure white. The flowers are of

Each. 10.

100. good size.

Louise Slocomb. A wonderful reddish garnet. Stems long and fine. Bush vigorous. Flowers keep well after cut. A Dahlia you should not fail to grow..-

Maid of the Mist. A deep cream shading to a beautiful salmon-pink on the outer petals which roll back to a depth of four inches, prettily pointed and twisted. Eight inches in diameter

Margaret Masson (Fisher \& Masson). Silvery lavender pink, very large, full form, excellent stem, strong grower. Very large striking variety that won many prizes and attracted much attention at last year's show. Highly recommended_._._._._-

Margaret Woodrow Wilson. Lilac lavender. Very large. Exhibition flower. Do not fail to have this for your collection. Most attractive. See R. C.--

Mary Steffenson. Citron yellow changing towards end to rosaline pink

Masterpiecs. Tango

Melody. Canary yellow, tinting to a creamy white, not a fine flower.

Mephistopheles. Red base outlined yellow

Mer. Wurfbain. We imported this variety. A dark shade of purple.

Millionaire. Light lavender flower large, a free grower. Pendent neck.

Mina Burgle. This splendid variety was raised by Burgle, gardener at the Mare Island Navy Yard. Color rich cardinal red. It is of fine form. The plant is a strong, vigorous grower, producing freely on long, stiff stems. $5 \mathrm{ft}$. We offer a select strain of roots

Miss Bridgeton. At one time considered the elite in the rose pink shades. It has not been a successful sort with us. Good grower and vigorous.........

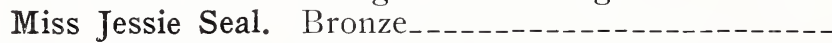

Molly Pitcher (Kemp). Strawberry red. R. C.--- 3.00

Mons Le Normand. Variegated yellow low tipped white. Sometimes comes solid crimson_._._._-

Mordella. A most charming and stunning bronze fawn. Full and deep. Long stems. 
SHADY LAWN NURSERIES : Hugo KiNd : HAMMONTON, N. J.

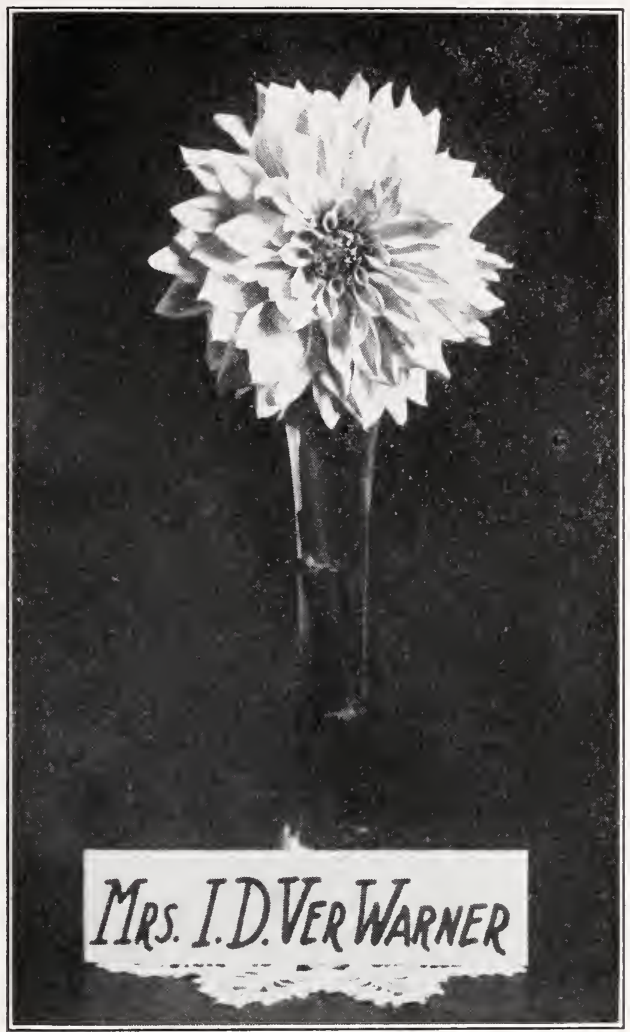

\section{DECORATIVE AND HYBRID VARIETIES-Continued}

Each. 10. 100.

Mr. C. H. Drusselhuis. For many years the variety Delice has been a favorite cut flower, and while beautiful it was not a free-flowering. In this new variety we have a similar color, a soft rose-pink with white suffusion toward the tips, and what is most important, one of the most prolific bloomers; of medium size, right for cutting and are splendidly supported on very long stems..-_-_-_-_-_-_

Mrs. Atherton (Dec.). Large free blooming of light yellow color

Mrs. Carl Salbach. Fine pink, long stems, ideal cut flower

Mrs. E. Davie. Light, pink, touches of lavender.---

Mrs. Eleanor Martin. A California sort. Mulberry red. Flower very large. Good stems, but not a

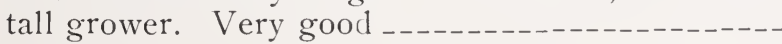




\section{DECORATIVE AND HYBRID VARIETIES-Continued}

Each. 10.100.

Mrs. G. W. Elkins. Bronze yellow, very large, not

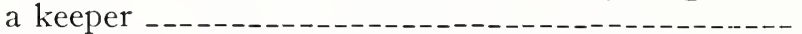

Mrs. Hartong. Buff yellow, old fashioned_-_-_-_--

Mrs. Helen Hollis. Brilliant red, not a keeper

Mrs. Hugo Kind. A large flower that is held on long, stiff stems. Of a velvety red and of the most attractive shade. Different than most reds. Petals are irregular and of the most pleasing form_-_-_--

Mrs. I. de Ver Warner (Marean). Orchid pink, very large, extra stem, strong grower, free bloomer, very satisfactory

Mrs. J. Gardner Cassatt. Bright cerise pink, large flowers on long, stiff stems

Mr. J. Harrison Dick. Here is the dahlia supreme for cutting or the garden. One of the most valuable new varieties of recent production. Color citron yellow at center, outer petals suffused and overlaid salmon pink, a lovely and effective combination, especially under artificial light. The plant is a wonderful grower of medium height and branching habit producing the perfect flowers in greatest profusion on long, stiff stems...-_._._.-.

Mrs. John T. Sheepers. Canary yellow, suffused pink on the outer petals. The huge blossoms are produced with great freedom_-_._-_-_-_-

Mrs. Lillian Baldwin. Listed under Lillian Baldwin.

Mrs. Nathaniel Slocomb (Decorative). A deep golden yellow of good form on long stems

Mrs. Thomas Burch (not the Mrs. Thos. Bush) (decorative). Similar to King of Autumn in form, buff, shaded

Mt. Shasta. Lister under Cactus. Bronze yellow overlaid tan and canary yellow. A wonderful color combination. Of the hybrid cactus type. The latter predominating. A lovely garden sort.-...-.--

My Maryland. A very large flower in lavender. Vigorous and free flowering. One of the prize winners in many shows. We offer rooted cuttings only. See R. C.

Myrah Hopping. Lavender. Large flower---_-_--

Myrah Valentine. Bronze. New 


\section{DECORATIVE AND HYBRID VARIETIES-Continued}

Each. 10.100.

Nobilis. Startling combination of scarlet and white, with white predominating. Large, bold blossom, on robust stem. Not free

Orange King. Orange yellow, not a keeper-

Oregon Beauty. Oriental red, large.

Oyster Bay Beauty. A very lovely red sort in the darker colors. Sometimes equals Elite Glory in size. Free and strong grower

Patrick O'Mara. Pronze.

Paul Michael or California Gold (Michael). Deep orange buff, fine form, good stem

Perfect Beauty. Light scarlet tipped white. One of Stillman's introductions that is always in demand.

Pink Perfection. Pink. Poor

Porthos (Called Blue Porthos). Purple shading to

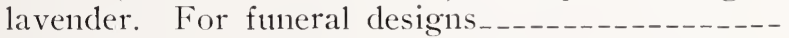

Porthos. Red. Prolific

Pride of California. Huge red

Princess Pat. Large flower and sturdy grower. Glorious shade of old rose. A splendid variety --

Queen Mary. A grand decorative that has proven its worth as the best deep pink for all purposes. The size is large, full high center, even up to November, when killed by frost. Color clear silvery cerise pink. The plant is a strong healthy, vigorous, upright branching grower, producing the flowers freely on long stems

Queen of the Garden Beautiful. This fine yellow was grown in the prison yards in California. A close competitor of Waldhein Sunshine_-_-_-_-_-_

Queen of the Market (Babylon). Red tipped white. Free. Small. _._.

Radium. Red and Gold.

Rainbow. A most wonderful coloring, old gold and

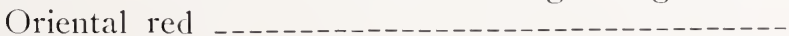

Red Devil. Carmine-red, as a rule comes tipped gold Robert Treat. Color American Beauty Rose_-_._--

Rodman Wanamaker. The world's best Dahlia and if not the largest in the world, is at least the largest stiff stem profuse blooming dahlia; blooms

$2.00 \quad 16.00$




\section{DECORATIVE AND HYBRID VARIETIES-Continued}

Each. 10.100.

are ten to eleven inches in diameter without disbudding. Color is entirely distinct; the buds are a light lemon yellow. As each petal expands the color changes chamelon like, to golden salmon with bronze suffusion (reflex, a beautiful spiral pink. A wonderful vigorous grower, with luxuriant bright, glossy green foliage. The flowers are most beautiful formed with long, irregular twisted and whorled petals, and produced freely on very long stiff stems, entirely distinct

$2.00 \quad 18.00 \quad 150.00$

Rosa Nell. Deep rose, very large and fine_-_---_----

Rose Fallon. Pink and autumn shades. A real pretty sort. -_-_-_-_-_-_-_-_-_-_-_-_-_-_-_-

Rosemawr. Large flower of rich rose pink_-_-_._-_-

Sagamore. Orange. Said to be the best in its color

Salbach's White. One of the finest whites in cultivation. Long stems and a good keeper. R. C. only.

San Mateo. Best fancy combination of deep yellow, striped and splashed scarlet. A large full flower.-

Senator Baird. Red. Good stems, but nothing wonderful

Shower of Gold. Golden bronze. Long stems. A very beautiful Dahlia. Petals of Chrysanthemum type

Shannon (Wigginton). Large bold flower in coppery orange

Somerset. Is a large decorative on excellent stems. Keeping qualities of the best if cut when the blooms have fully matured. Blooms freely. In fashioning this flower the genii of nature have blended the color tones in a manner that makes description difficult. But while the color somewhat varies according to weather conditions and the age of the flower, the general effect is that of salmon and old rose. As the blooms mature, the salmon changes into old rose, and like an after-thought, sometimes, there is a touch of lavender there. There is just a slight twist to the petals and irregularity in the arrayal of same, which gives the flower an air of grace and refinement that is lacking in most large dahlias. Somerset is a healthy and vigorous grower, that you will not need to spray and dust or worry lest some insect give it a cross look. Even Dia- 


\section{DECORATIVE AND HYBRID VARIETIES-Continued}

brotica (green, black spotted lady bug) will not touch it as long as there is something else to eat in the garden. Somerset has proved its value as an exhibition flower. Scored 90 points. See R. C.-

Souv. de Gus Doazon. Scarlet red, large

Stunner. Giant exhibition flower of an attractive light yellow color-_-_-_-_-_-_-

Susan G. Tevis (Boston). Deep lilac flower with strong stem. Blooms profusely early and late_---

Sylvia. Deep pink

Theo Vail. Old gold shading to apricot_

Tommy Atkins. Remarkable for its wonderful coloring. Brilliant flaming scarlet with golden metallic lustre, the brightest and richest red yet produced. The flowers are very large but not at all stiff or formal and are well placed on good long stems; early flowering and continues good to the end of the season; splendid for exhibition, the garden, or for cutting

Trentonian. A mammoth Dahlia of fine quality. Excellent for exhibition purposes. Colors are of the autumnal shades. R. C.

Tut. A dahlia that is unusual from other variegated sorts. Yellow, bronze and red. Striped and splashed like a Sioux Indian on the war-path. All colors gayly intermingled. Plant is of perfect growth. Flowers are borne on straight even stems_-_._-_-

Typhine. Bronze and Red

U. S. A. Very large, red orange. Poor_-_._-_-_-_-

Valley Forge. A large purple variety on fine long stems. Excellent for exhibition. Vigorous and sturdy

Venus (Marean). Cream white tinted lavender, medium size, good stem, dwarf grower, free bloomer

Waldheim Sunshine. There are many yellow Dahlias I must confess this has been our largest in the hybrid decorative. Well known among all exhibi-

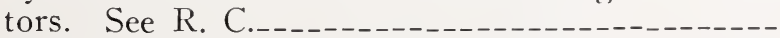

Watchung Sunrise. Another close competitor of the above. Extremely large, though the flowers predominates in yellow it is well overlaid with a marvelous shade of old gold and pink 


\section{DECORATIVE AND HYBRID VARIETIES-Continued}

Each. 10.100.

Watchung Sunset. Grand flower. Mammoth in size. Like the sun setting in the Watchung Mountains. Pink in all its grandeur.

Wm. Reed Butler (not the Daddy Butler). A free flowering white

Whopper. A giant decorative with extremely large, well-built deep flowers of a most pleasing shade of yellow-buff, suffused with orange. In form it is all that can be desired.

Wizard of $\mathrm{Oz}$. A great dahlia from all points of view, size, formation, color, habit of growth and freedom of bloom. Really a wonderful all around dahlia, be it for the garden, exhibition or cut flower. Begins to flower early and holds its blooms perfect to the end of the season; these are produced on long, stiff stems held so as to show them off to the very best advantages. In color it is a rare shade of amber-pink with soft salmon shading or suffusion. Always attracts great attention_._._._._.-.

World's Best White. Considered by some the best white.

Yellow Collose. Bright yellow

Yellow Duke. Primrose yellow

Zikola. Free flowering bronze good cut flowers_...-

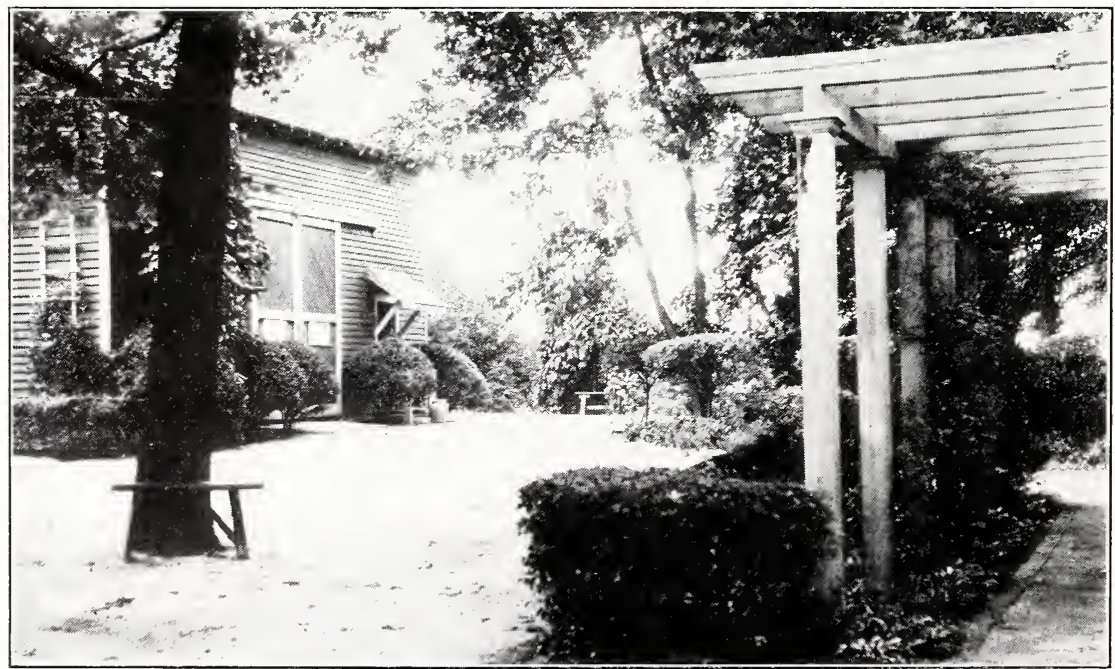

Warehouse at Shady Lawn. 


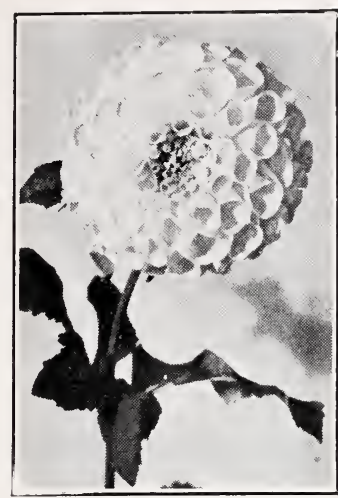

Maude Adams.

\section{Show or Ball Dahlias}

Each. $10 . \quad 100$.

A. D. Livoni. Shell pink. free, early

8.00

American Beauty. Red

Bronze Blue. A fine blue. Long stems

Cuban Giant. Garnet_....-

D. M. Moore. Large dark maroon

Dreer's White. Large white. Free and early_-.--.----

Dreer's Yellow. Go $1 \mathrm{~d}$ e $n$ yellow

Double Check. Saffron base. Checked and double checked. Red. Very novel

Elsie Burgess. Lavender

Elm City. Bronzy vellow, suffused amber and tipped red

Fireburst. Bright red

Gold Medal. "Kind's Gold Medal." Of all the show Dahlias we have, here is a Dahlia all by itself. The reader may recall the older variety of Gold Medal. A yellow base with markings of bronze. Ten years back we found a sport from this particular sort which proved to retain its character. The color is of a most pleasing coppery bronze. Many of these flowers are shipped to the New York and Philadelphia markets. A color always wanted by the decorator. Consult your wholesaler as to his opinion on this particular Dahlia. Through a misunderstanding this Dahlia was given other names as "Gold Medal De Luxe," etc. There are the three strong points why you should have this Dahlia in your collection: A most desirable color, long sturdy stems, always in demand

John Thorpe. Lavender pink

Maude Adams. White and lilac, suffused, flower soft.

Mme. De La Moure. Cerise pink, free and fine, red markings

Mrs. G. C. Anderson. This excellent red is very popular. A fine cut flower. Fine long stems._._.-. 
SHADY LAWN NURSERIES : Hugo KIND : HAMMONTON, N. J.

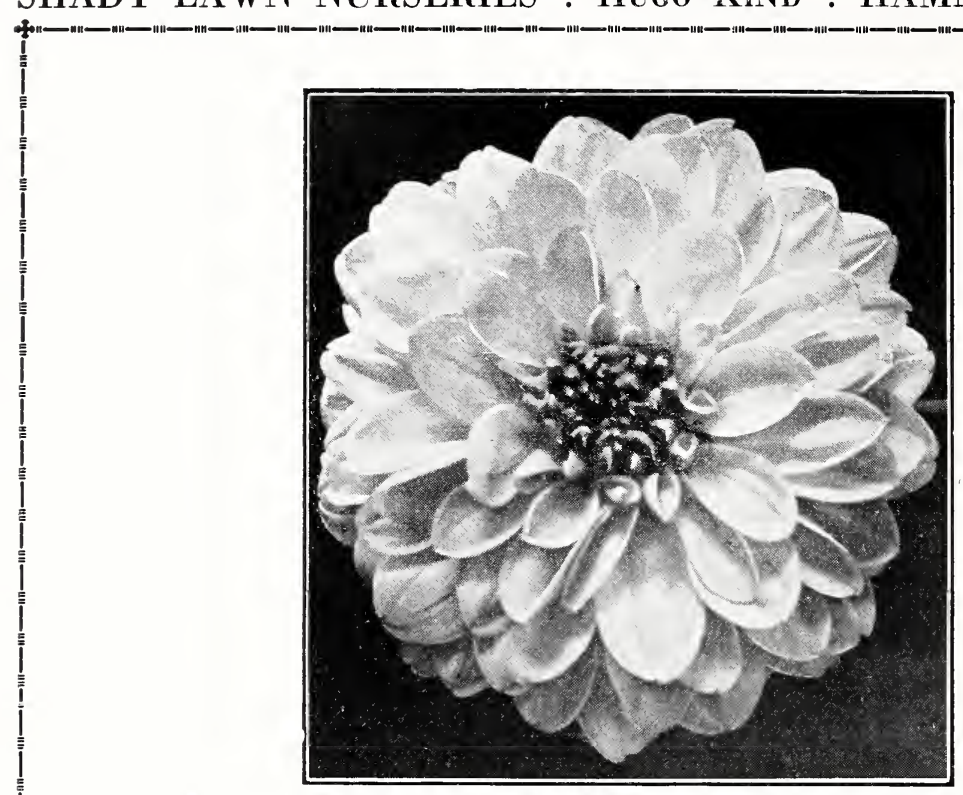

MIrs. G. C. Anderson-1/3 natural size.

\section{SHOW or BALL DAHLIAS-Continued}

Each. 10.100.

Peacock. A combination of lavender blue and white.

Very attractive. The best of this type_- $1.00 \quad 9.00$

Progressive. Lavender pink _-_-_- $\quad 1.00 \quad 8.00$

Queen Victoria. Yellow _._. $1.00 \quad 8.00$

Red Grand Duke. Cardinal red_____._._. $\quad 1.00 \quad 8.00$

Rose. Rose pink, long stem, not a keeper_-_-_-_- $\quad 1.00$

Snowdon. White, not a keeper______-_._._. 1.00

Vivian. Old rose and white_._. $\quad 1.00 \quad 8.00$

Wagner. Probably the largest show dahlia in our collection. Immense flower of a chrome yellow shading deeper at ends. A prize winner for size, poor stem _......... 3.00

White Swan. White, free-__- $1.00 \quad 8.00$

W. W. Rawson. White quilled petals suffused lilac-- $\quad 2.00 \quad 18.00$

"Your Dahlias have the most vitality in the world," writes a customer from the Pacific Coast.

"I won sweepstakes with your Dahlias," writes a party from the South. 
SHADY LAWN NURSERIES : Hugo KIND : HAMMONTON, N. J.

\section{Single or Century Dahlias}

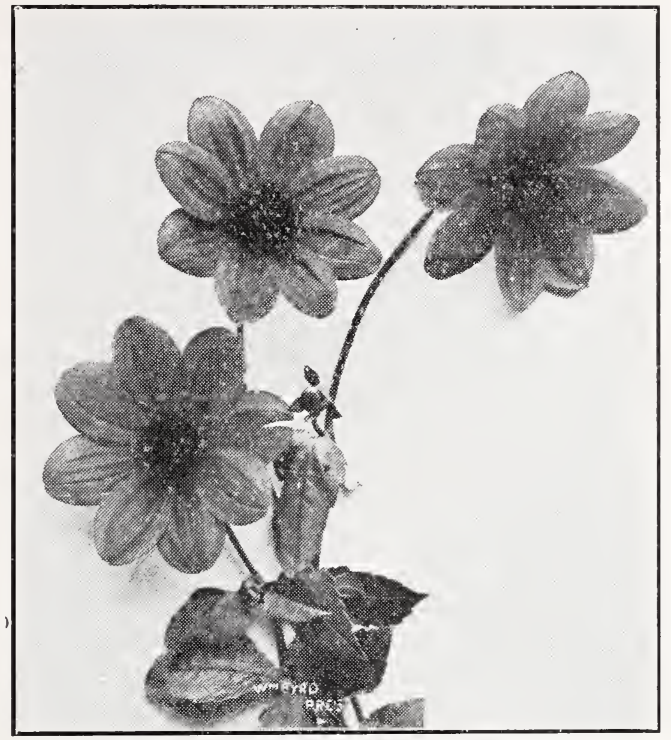

Rose Pink Century.

Each. 10. 100.

Alva. Yellow, speckled and tipped with pink_--_-.--

Ami Barillet (Lucifer). The purple foliage Dahlia. Entirely distinct. Flowers pure garnet, rich and glowing with a dark center, until the pollen appears. A free bloomer and strikingly effective for all purposes

$2.00 \quad 18.00$

Apple Blossom. Pretty single apple blossom shades.

Autumn Century. Old rose and yellow_-_-_-_-_-

1.008 .00

Ceres. A good pink

1.008 .00

Cardinal. Cardinal red________.

Cream Century. Creamy white

Fedora. Bright yellow, heavily striped bright-red_--

Fringed 20th Century. Pink, shading to white,

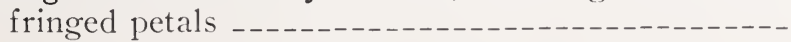


Geisha Century. Red and yellow

Each.

10. 100 .

Gloxinia. In marking and brilliancy of color resembles the gloxinia so much to suggest the name-

Golden Century. Golden and yellow

John Lucas. Apple blossom pink and white. Very large flower

Lucifer. Known as Ami Barillet

Nymphea Century. White yellow toward center----

Rantendelien. Red, tipped white

Rose Pink Century. Rose. The finest of all Pink Centuries

Sachem. A beautiful orange-scarlet

Scarlet Century. Scarlet

20th Century. Pink shading white

White Century. White

\section{Collarette Dahlias}

Albert Maumerne. Velvety crimson, purple with white tips

Each. 10.100.

Banker. Rich scarlet, collar petals scarlet tipped yellow

Diadem. Red

Dorian. Rich crimson, shaded maroon; collar white_

Elgrave. Duplex collarette, most novel and effective, with two or more rows petals; rich maroon, collar petals maroon heavily tipped white

Fayette. Bright scarlet with light yellow collar

Marley. Yellow and old rose

Maurice Rivor. Rich crimson maroon

Mons. L. Ferard. Carmine, white and purple collar_

Prince Carnival. Very large and fine. Soft rosy red-like color

Traymore. Red, yellow collar 
SHADY LAWN NURSERIES : HugO KIND : HAMMONTON, N. J.

\section{Peony Dahlias}

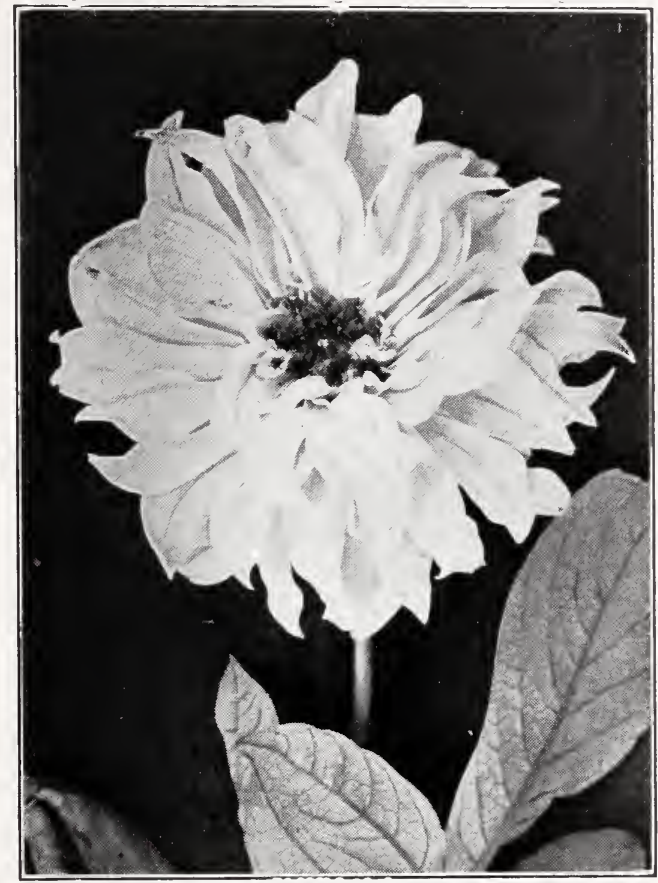

Caroline winters.

Each. 10.100.

A. C. Ide. Dark garnet_- $1.00 \quad 8.00$

Andrew Carnegie. Salmon pink___- $\quad 1.00 \quad 8.00$

Big Chief. Red - $\quad 1.00 \quad 8.00$

Canada. A fine fluffy white_____ $\quad 1.00 \quad 8.00$

Caroline Winters. Bronze. Petals of a feathery type $\quad \begin{array}{lll}1.50 & 12.00\end{array}$

Chateney. Pink _. $\quad 1.00 \quad 8.00$

Cleopatra. Red and yellow___- $\quad 1.00 \quad 8.00$

Count Zeppelin. Cactus Peony. Fine silvery pink. Excellent for basket effect. - $1.00 \quad 9.00$

Devotion. Large pink, free-______- $\quad 1.00 \quad 8.00$

Diana. Dark red, large-___- $\quad 1.00 \quad 8.00$

Geisha. Gold and red_-_-_- 3.50

Glory of Baarn. Lavender____-__-_ $\quad 1.00 \quad 8.00$

Glory of Nikerk. Deep claret purple____-__-_ $\quad 1.00 \quad 8.00$

Mrs. Jacques Futrelle. Yellow, heavily splashed $\quad 1.00 \quad 8.00$ 


\section{PEONY DAHLIAS-Continued}

Mrs. Ellen Kelley. Yellow

Each. 10. 100.

Mary Jane. A fine flesh pink

$1.50 \quad 12.00$

Mme. Biestin. Lavender, free.

$1.00 \quad 8.00$

Nokomis. Yellow, heavily striped red, a showy and fine flower, sometimes comes solid red.--_-_-_---

$1.00 \quad 8.00$

Pride of Portland. Yellow and red. Good.--_----

$1.00 \quad 8.00$

2.00

Princess Juliana. White free bloomer. A fine cut flower

Queen Elizabeth. The lavender that has not yet been beaten. Long stems, free bloomer, a fine flower indeed

Queen Emma. Hollyhock pink.

1.00

8.00

Stacy Trent. Silvery pink.

2.00

William Kerr. Red and yellow.

1.00

8.00

\section{Pom Pom Dahlias}

Allie Morey. Rose-_-_- 1.50

Amber Queen. Amber-_-_-_- 1.00

100.

10.

$1.00 \quad 8.00$

Ariel. Orange buff, extra fine small flowers

$1.50 \quad 14.00$

Catherine. Bright yellow

$1.00 \quad 8.00$

Clarissa. Purple. Extra fine

$1.50 \quad 12.00$

Darksome. A very dark red.-_-_-_-_-_-_-_-_-_-

$1.50 \quad 14.00$

Eleganta. Purple shades_-_-_-_-_-

$1.50 \quad 14.00$

Elizabeth. Bronze --_-_- 2.00

Fairy Queen. Yellow, Pink shading--_---_------

Flame. Red; a cut flower

Joe Fete. White

Klein Domittea. Bright amber. Very good

2.50

Little David. A fine red_.

4.00

Little Bessie. Red

Madeleine. Red, variegated white. The leading pom pom of this color, long stems and a very fine cut flower variety

Pink Beauty. Soft pink. Good_

Rosalie. Old rose and white, not good

Rothaut. Fine red -

Snow Clad. White, free bloomer 


\section{DECORATIVE \\ MINIATURE POM POM DAHLIAS}

These new and handsome varieties found most interesting.

Caronna. White.

Each. 10.100.

Charlotte, Red Orange_____-_._- $.50 \quad 4.00$

Daybreak, Orange-Apricot _-_________- $.50 \quad 4.00$

Little Jewel. Pink_____._. .503 .00

28.00

Garden Love. Old Rose-_______ $.50 \quad 4.00$

Good Luck. Deep Bright Orange_________- $.50 \quad 4.00$

Rapallo. Carmine tipped. Gold _-_____- $.50 \quad 4.00$

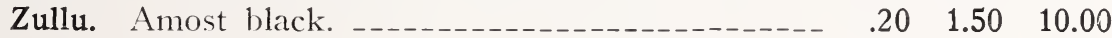

DOUBLE DAHLIAS UNDER COLOR

Lavender

Pink

Red

White

Yellow

Assorted

We have several thousand clumps in red, pink, white and yellow, at $\$ 9.00$ per $100 ; \$ 70.00$ per 1000 .

\section{POM POM CACTUS}

Harzer Kind. Harz a forest in Germany, Kind a child. This dahlia was imported years ago. Lavender pink. Fine for minature basket work-_._._-_

Coronation. We imported this sort from England several years back. Bright red. Flowers small. Unique.

\section{FLORISTS SUPERFINE MIXTURE}

Contains Jersey Beauty, Jersey Beacon, Ida Ver Warner, Marg. Mason and a score of other fine sorts_-

\section{Dahlia Seed}

Per 100.

California Seed. Selected from good varieties. $\$ 2.00$ 


\section{Rooted Cuttings}

Rooted cuttings have been one of our most successful items among our Dahlia offerings. They not only give the first year the best exhibition flowers but save you many dollars by procuring at low cost the best high priced varieties. We have shipped them to almost every state in the Union and the testimonial letters received have been most gratifying.

\section{HOW TO CARE FOR CUTTINGS WHEN RECEIVED}

Unpack immediately, place in $2 \mathrm{I} / 4$-inch pots or plant in shallow flats of soil. Shade for several days. Many of our customers report placing cuttings in the open field. Though this method of planting may be successful in a rainy period, one takes chances should hot, dry weather set in. Another good way when danger of frost is past is to plant in cool frames. Cheese cloth makes an excellent shade and also prevents draft from reaching the cuttings.

By this method stock will be ready in ten days and cuttings may be lifted with good soil adhering to roots. Always water well before lifting cuttings. An inexpensive way of shading in open field is to use magazine pages and placing a little soil at both ends. It is surprising how the moisture will remain under this covering.

Orders booked in rotation.

Charge orders not accepted on rooted cuttings.

No cuttings will be sent out earlier than Fcbruary 1st. Stock shipped only at customer's risk.

Cuttings not returnable.

Ambassador (C.)

Each. 10.

100.

American Triumph (C.) _._._. 1.00

Arbutus (D.) _. 20

2.50

Avalon (D.)

$.25 \quad 1.25$

Barbara Wear (D.)

$.50 \quad 4.00$

Barbara Redfern (D.)

$.20 \quad 2.00$

Bob Pleause (D.) _. 20

1.50

14.00

Cigarette (D.)

$.15 \quad 1.00$

City of Trenton (D.)

Countess of Cleverly__._. 75

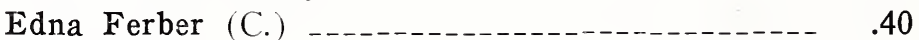

Eva Quadling

Eliza London Shepard (D.) _._._._._. 1.00

Emma Marie (C.)

Eliza Clark Bull

Fort Mammoth

Goodnight

Harry Mayer (D.

Islam Patrol

(D.)

Jack O'Lantern (D.) 
DAHLIAS-ROOTED CUTTINGS-Continued

Jane Cowl (D.) See page -

Each. 10.100.

Jersey's Beauty (D.) Per $1000 \$ 75.00$

Jersey's Sovereign (D.)

$.15 \quad 1.00$

9.00

Jersey's Beacon (D.)

$.25 \quad 2.00$

Kathleen Norris. See page -

$.20 \quad 2.00 \quad 16.00$

Kemp's Violet Wonder (D)

$.40 \quad 3.50$

Kentucky (D.)

1.50

King Midas (D.)

$.90 \quad 8.00$

Leo Niessen (D.)

$1.50 \quad 12.00$

Margaret Woodrow Wilson (D.)

$.40 \quad 3.50$

Mariposa (D.). See page 8

Metta Scammel (D.)

$\begin{array}{ll}.50 & 4.00\end{array}$

My Maryland (D.)

$\begin{array}{ll}.65 & 6.00\end{array}$

Mrs. E. Martin (D.)

$.25 \quad 1.50$

Molly Pitcher (D.)

2.00

N. J. Chamber of Commerce. (D.)

Norths Yellow (D.)

$.90 \quad 6.00$

$\begin{array}{ll}.25 & 2.00\end{array}$

Pop Stewart (D.)

$.40 \quad 3.00$

Post Telegram (D.)

$.40 \quad 3.00$

Regal (D.)

$1.00 \quad 9.00$

Robt. E. Lee (D.)

1.00

Robert Treat

Rodman Wanamaker (D.)

$\begin{array}{ll}.50 & 4.50\end{array}$

35.00

Rollo Boy (C.)

Hazel Heitter (D.)

$1.00 \quad 9.00$

Sagamore (D.)

Per $1000 \$ 90.00$

Salbach's White (D.)

$.15 \quad 1.50$

12.00

Salmon Supreme (C.)

$.30 \quad 2.50$

$.90 \quad 9.00$

Somerset (D.) See special.

The World (D.)

Thomas J. Edison

(D.)

2.00

Treasure Island

Trentonian (D.)

$1.00 \quad 9.00$

Uncle Tom

Waldheim Sunshine

$\begin{array}{ll}.50 & 5.00\end{array}$

Watching Sunrise

$.60 \quad 6.00$

Watchung Sunset

(D.)

2.00

Walcheim Wonder (D.)

1.00

World's Best White (D.)

$\begin{array}{ll}.50 & 4.00\end{array}$

William Hogan

(D.)

$1.00 \quad 8.00$ 


\section{Four Specials}

\section{Rooted Cuttings}

3 at 10 rate - -25 at 100 rate

250 at 1000 rate

\section{JANE COWL-Bronze}

Each 35 c; ten for $\$ 3.00 ; 100$ for $\$ 20.00$;

1000 for $\$ 180.00$

\section{KATHLEEN NORRIS-Pin'}

Each $90 \mathrm{c}$; ten for $\$ 8.00 ; 100$ for $\$ 75.00$;

1000 for $\$ 4.00 .00$

MARIPOSA-Lavender

Each 25c; ten for $\$ 1.25 ; 100$ for $\$ 12.00$;

1000 for $\$ 90.00$

SOMERSET-See description on page 24 Each $25 c$; ten for $\$ 2.00 ; 100$ for $\$ 15.00$; 1000 for $\$ 125.00$

\section{Orders Booked in Rotation}




\section{Gladiolus}

Not less than 25 of a kind; $1 \frac{1}{2}$ inches and up.

Altair (Kunderd). Very early; pure apricot color

1000

Byron L. Smith. Blue

Duchess of York. Deep purple_____ 3.00

14.00

E. J. Shaylor. Considered the best ruffled pink for cut flower use

Evelyn Kirtland. Flowers a beautiful pink

Fern Kyle. White and fine. Ruffled_____________- 4.00

35.00

Golden Queen. Yellow

Los Angeles. Pink

$2.00 \quad 18.00$

Helen Franklin. White, finely rufflecl___-___-___-_.00

18.00

Maidens Blush (Prim). Delicate salmon pink, slightly flushed light rose, tall growing, very early_-_-_-_-_---- 1.00

Mrs. Frank Pendleton. A beautiful rose pink on a pure white background with deep rich velvety blood red blotches on lower petals_________ 2.50

Mrs. Phipps. Large pink____ 10.00 90.00

Myrtle. Lavender____ 1.50 14.00

Nyrah. A fine yellow 28.00

Odin. Pink. Early. Good forcer. Fine cut flower-_-_- 3.00 $28.0^{\prime}$

Primulinus Hybrids. A new race of remarkable dainty and beautiful gladioli. Perhaps orange and gold colors predominate, but they combine every shade in the rainbow. Usually the flowers are hooded. Somewhat smaller than the ordinary Gladioli and the stems are gracefully curved. Very early _-_._- 1.00

Rose Precose. Pink

Sentinel. A tall and strong rose-pink flaked a darker on the edge and blending to a white throat. Very late_...-

Sheila. Bronze. Good _._.

Vanity. Very tall. Pink. $5 \mathrm{ft}$ spikes

Venus. Pink, very fine-___-__- 2.00

Virginia. The leading early red Gladiolus of today. Ruffled _..._._.

War. Deep red, large flower-___ 4.00

Mixed

We have from 50,000 upwards of Maiden Blush in second sizes. Planted late, fall flowers may be obtained. $\$ 50.00$ per 10,000 . 
SHADY LAWN NURSERIES : Hugo Kind : HAMMUNTON, N. J.

\section{Pom Pom Chrysanthemums}

Pom Poms. With the exception of Zenobia these are offered in out door grown clumps.

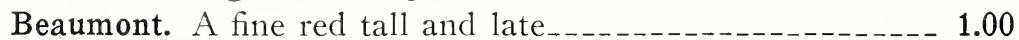

Pink Dandy. Silvery pink. Astor type

Sunshine. Aster type. Late yellow____________._. 2.00

Zenobia. Button type. Early. Yellow and bronze. One of the first to bloom and always a money maker as it flowers after Dahlias are on the wane. Rooted cuttings only.

\section{Hardy Perennials}

(Not less than 3 of a kind)

Except when listed singly.
2 year stock offered Except where noted.

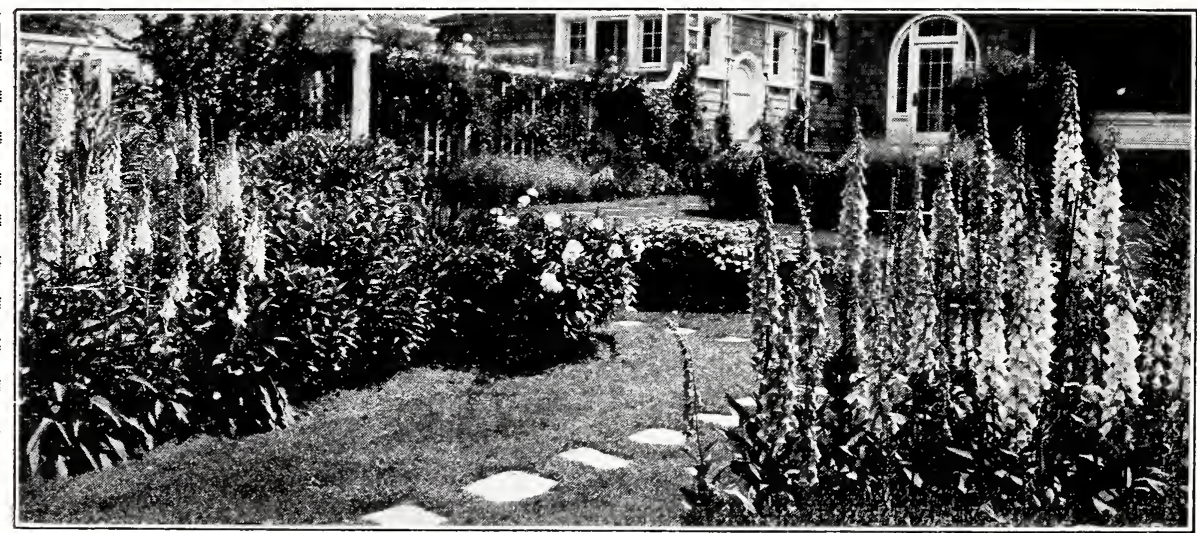

Achillea

10.

Boule de Niege

Althea or Hibiscus

Red, 3 yr. Double

8.00

White, 3 yr. Double

Aquilegia

Hybrids

Asclepias

Tuberosa

Artemesia

Silver King 
Aster

10. 100 .

Tartarica -

Astilbe. Extra heavy.

Queen Alexander -

Peach Blossom - 4.0035 .00

Kriemhilde -

The above varieties are all fine forcing sorts. The clumps offered are extremely large and heavy and we recommend calling for them. They must be first frozen if wanted for forcing. Make excellent pot plants. Planting sizes with exception of Kriemhilde at $\$ 4.00$ per 100 . Light and easily shipped.

Bleeding Heart (Dielytra Spectabilis)_-_-_-_-_-_._- 3.0028 .00

Clematis

Paniculata -

Jackmani _-__-_-_- 3.00

Coreopsis

Lanceolata, 1 yr. -_-_-_-

Lanceolata, 2 yr. -

4.00

6.00

Daisies

Alaska _-_._._. .75

Hartje \& Elder (new). Improved daisy. Cut flower sort. $\quad .75$

6.00

6.00

Delphiniums

Belladonna, 1 yr. _... 1.00

Belladonna, 2 yr.

6.00

Bellamosum, 2 yr.

$\begin{array}{ll}1.50 & 10.00\end{array}$

English Hybricls, 2 yr.

$2.50 \quad 18.00$

\section{Eupatorium}

Coelestinum _..._. 1.00

8.00

Funkia (Hosia)

Albo Narginata (small leaves)

Aurea (green yellow stripe)

Corealea (blue flower, large green leaves) _-______-_ 1.00

Glauca (bluish leaves) -__ 2.00

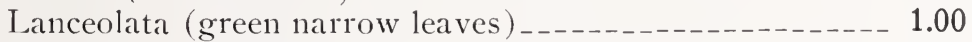

Plantizina (subcordato undulata)

Variegated (Undulata variegata)________________- 1.00

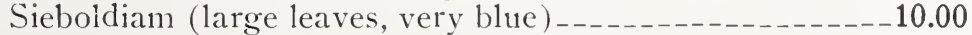

Gerberia

(African Daisy) _._._. 3.00

28.00

Grasses

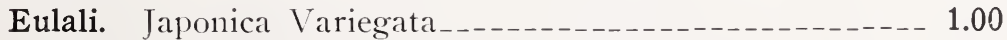

8.00

Eulalia Zebrina _-_._- $1.00 \quad 8.00$

Eulalia Japonica -

Phalarnius Japonica - 
SHADY LAWN NURSERIES : Hugo KIND : HAMMONTON, N. J.

\section{HARDY PERENNIALS-Continued}

Gypsophila

Paniculata

Flora Plena

Erhlie (Per $1000 \$ 200.00$ )

$3 \mathrm{yr}$. will flower freely first year

Bristol Fairy. Almost identical to Erhlie

$3.00 \quad 25.00$

\section{Hemoracallis}

Lemon Lily

1.00

Orange Double

Orange Single

\section{Iris (German)}

Atropurpurea, purple -

Black Prince, black _._._._. .50

Chereax _-_._- 50

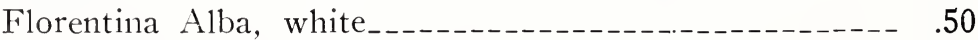

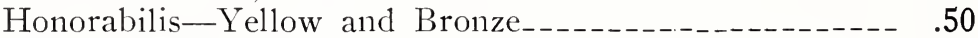

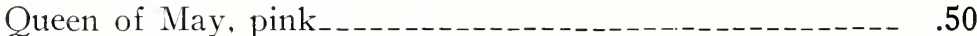

Sherwin, bright yellow _._.

Under color, per $1000, \$ 15.00$; per $10,000, \$ 125.00$.

Iris (Siberian)

Blue, strong clumps

White

\section{Iris (Dwarf) Pumilo}

These cute little iris attain a height of only four inches.

Fine for rockery or borders. Rare and unique.

Blue

Yellow

Japanese Iris-Named Varieties (All six petal.)

Iso-no-nami

Gelska-no-nami

Enna-no-nami

Astarte

Mahogany

Uchiny

Kolsi-no-cls

Hercules

Melpenomi

Gold Bond

Mixed

Liatris-2 year except where noted.

Pycnostachya, 1 yr.

Pycnostachya-Tall and fine, handsome cut flower 
Lily of Valley-Convularia

10100

Pips (per M \$12.00)_-_-_-_._-

Clumps

Marshmallow (Hibiscus)

Red, Pink and White

\section{Matricaria}

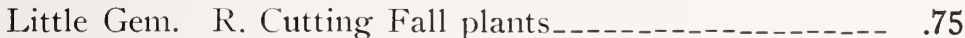

Stock Plants

Myosotis (Forget-me-not) _._._. $\quad .50$

Monarda. Rosea

Pachysandra

Radicans

1.00

Peony, 3-5 eye, extra fine.

Rubra Superba

Festiva Maxima

Albert Crousse

Assorted

2.00

Officinalis Rubra

3.00

Phlox (Hardy)

Strong 1-year-old field grown plants.

Antonin Mercie, lilac_______ 1.00

16.00

Beacon Cherry, red

1.00

Mrs. Jenkins, best pure white

1.00

Mrs. Lingard

Rheinlander, salmon pink, red eye-_-__-__-_-_-_-_ 1.25

Rynstrom, carmine rose

1.25

Thor, deep salmon pink

1.25

Mixed

28.00

\section{Physalis Franchetii}

Japanese lantern plant_-__ 1.00

Rudbeckia

Golden Glow - 1.00

Purpurea

Sedum. Spectabilis ___

Tritoma

Pfitzeri

Tuberoses-Virginia grown. The Pearl, 10 for 50c; 100 for $\$ 3.00$; per $1,000, \$ 20.00$. Sizes in number one bulbs. 10,000 can be furnished for $\$ 17.00$ per 1,000 .

\section{Viola}

Pedata (fine for rockeries)

Odorata (sweet scented)

Lutea (yellow)

\section{Yucca}

Filamentosa

Variegated-Fine, large plants for lawn planting 
SHADY LAWN NURSERIES : Hugo KINd : HAMMONTON, N. J.

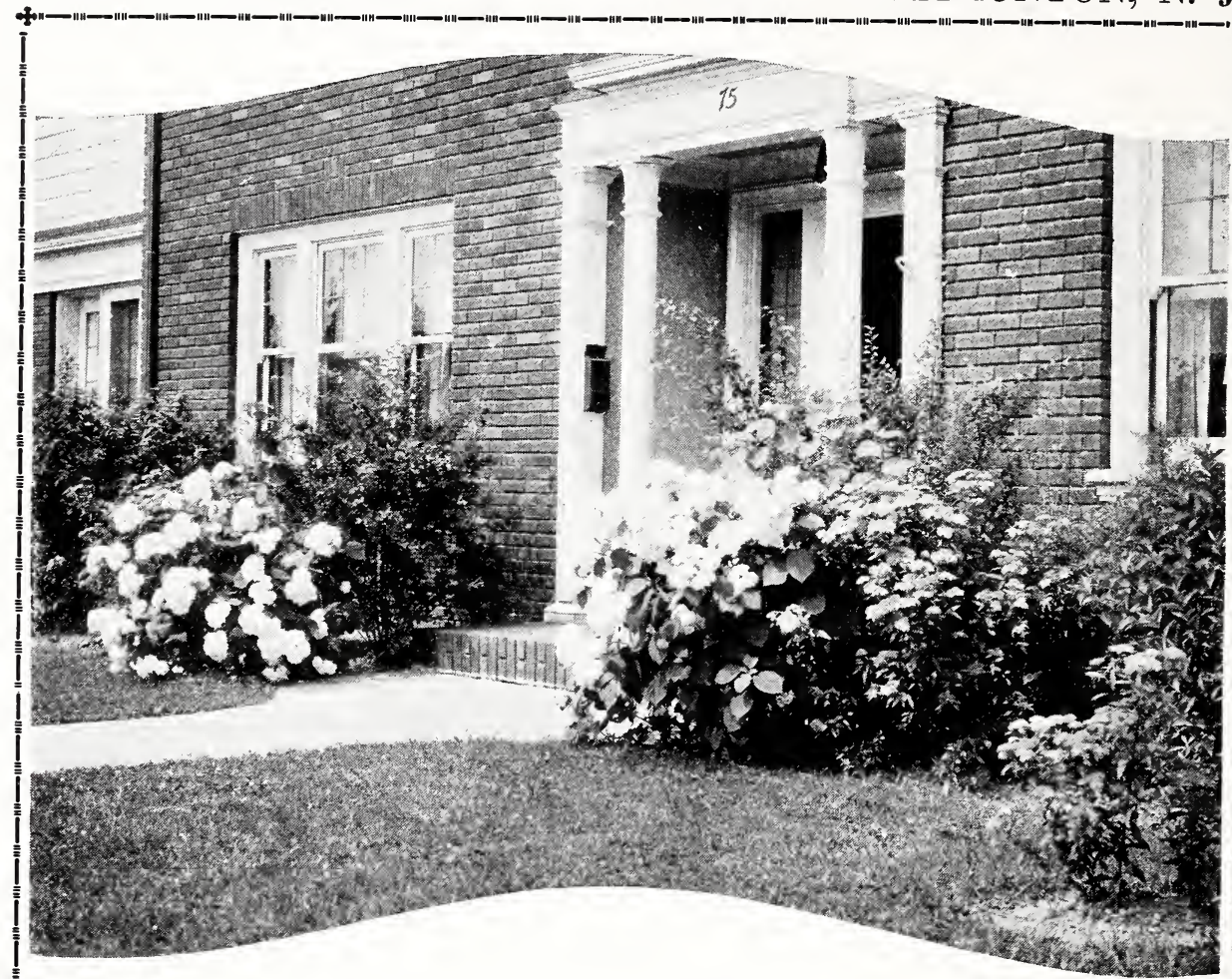

\section{Hardy Shrubbery}

All Stock is Transplanted, Bushy and Well Grown.

Elthea (Rose of Sharon). 18 to 24 in. asst.-------

Amygdalis

SHADY LAWN NURSERIES : Hugo KIND : HAMMONTON, N. J. 


\section{Boxwood}

Sempervirans, 8 to 12 in. bushy, fine

Suffruticosa, 3 to 6 in.

Suffruticosa, rooted cuttings

Butterfly Bush. Fine strong transplanted stock----

Button Bush

Callicarpa Purpurea

Caryopteris (Mastacantha)

Clethra Alnifolia (Pepper Bush)

Corchorus or Kerria Japanica fl. Plena

Cornus (Dogwood) transplanted

Florida (White)

Rubra (Pink)

Paniculata (Gray Berries)

Craetagus (Hawthorne)

Paul's Scarlet. Pink flowers 1 n early spring --_-_-

Crepe Myrtle. Pink

Cydonia Japonica, 2 ft. -

Deutzia, fine and bushy

Rosea Plena, $3 \mathrm{ft}$.

Gracilis, $3 \mathrm{ft}$.

P. Rochester, $3 \mathrm{ft}$

Exochorda Grandiflora

Pearl Bush

3 to $4 \mathrm{ft}$. at

\section{Forsythia}

Fortunei, 2 to $3 \mathrm{ft}$

Viridissima

\section{Genista}

Terictoria, $3 \mathrm{ft}$.

Halesia

Tetraptera

Holly

Opaca, $2 \mathrm{ft}$.

Honeysuckle (Bush)

Pink, White and Red

\section{Hydrangea}

Hills of Snow

Paniculata Grandiflora. Bushy.

Otatska (Blue)

$2 \mathrm{I} / 4$ in. pot plants

Rooted cuttings

Jasmine (Abelia Grandiflora), 2 yr.

Judas Tree (Pink Flowers)

$2 \mathrm{ft}$.

3 to $4 \mathrm{ft}$.

Koelrutia Paniculata
Each. 10.

100.

$4.00 \quad 35.00$

$5.00 \quad 40.00$

$\begin{array}{ll}4.00 & 35.00\end{array}$

$1.50 \quad 12.00$

2.00

4.00

38.00

4.00

1.00

8.00

$3.00 \quad 28.00$

3.00

25.00

5.00

3.00

25.00

2.00

3.00

3.00

4.00

$.30 \quad 3.00$

$.45 \quad 4.00$

3.00

.30

$3.00 \quad 25.00$

$3.00 \quad 25.00$

3.00

3.00

3.00

3.00

.75

.50

25.00

6.50

3.00 


\section{HARDY SHRUBBERY-Continued}

Larche

European. This deciduous evergreen is quite rare.

3 to $4 \mathrm{ft}$.

Lespedeza. Bicolor. 3 to $4 \mathrm{ft}$.

Each. 10.100.

Lilac

Named 10 varieties. Double, single. 3 to $4 \mathrm{ft} .----$

Lonicera (Bush Honeysuckle)

Tatarica, 2 to $3 \mathrm{ft}$.

Pink, White, Red

Magnolia (rare)

Soulangeana, 18 in, 24 in._._._._. 3.25

Maples (Japanese grafted)

Purpurea, 18 in.

Norway, 4 to 5

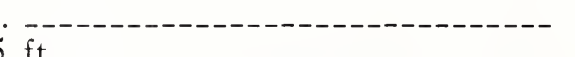

Malus (Flowering Crab)

Atrosanguinie, 2 to $3 \mathrm{ft}$.

2.00

$.60 \quad 5.00$

2.00

Mountain Ash

Beautiful trees, transplanted 5 to $6 \mathrm{ft}$.

Weeping

Philadelphus (Mock Orange)

Lemoine, 2 to $3 \mathrm{ft}$., fine

Coronarious, 2 to $3 \mathrm{ft}$.

2.00

Photina Villosa

$3 \mathrm{yr}$.

Privet. California, 1 yr. $1,000, \$ 16.00$

California, 2 yr.

Mammoth plants, 8 to $12 \mathrm{ft}$.

Variegated, $18 \mathrm{in.}$

Robina Hispida

Rose

Roses (Rambler). 3-year transplanted.

Dr. Van Fleet. Pink

$3.50 \quad 30.00$

Pauls Scarlet Climber

$3.50 \quad 30.00$

Yellow Rambler

$3.50 \quad 30.00$

$3.50 \quad 30.00$

White D. Perkins

$3.50 \quad 30.00$

Roses (Moss). 3 year.

Pink

$3.50 \quad 30.00$

White -

Sophora (Japanese Pagoda tree) (rare).

Japonica, $4 \mathrm{ft}$.

$3.50 \quad 30.00$

\section{Spirea}

Anthony Waterer

Billardi Pink

$1.00 \quad 6.00$

Billardi White -

Douglasi

Thunbergie 2.00

Tamarix (African) Large specimen bushes

Vaccinium Corymbosum (Blue Berry) 
Vitex Agnus-Castus
Weigela
Eva Rathke, large
Rosea. Extra strong plants
Lutea -60
Vines and Creepers

Ampelopsis Veitchi. 2 yr.

$1.50 \quad 14.00$

Ampelopsis Quinq. 3 yr.

$2.00 \quad 16.00$

English Ivy. R. C., 10 in. vines

$1.00 \quad 8.00$

\section{Fruits}

2 yr. select

GRAPES

10. 100

Agawam -

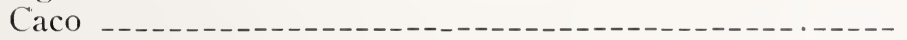

Campbell's Early -..-_-

Catawba

$\begin{array}{ll}1.00 & 8.00\end{array}$

$2.50 \quad 20.00$

$\begin{array}{ll}1.50 & 14.00\end{array}$

Champagne Grape. A sterling variety of greatest merit. Color of coppery red. Berries very large. Immense producer. This season in which other varieties did not fruit, this variety stood out bearing an immense crop, very strong grower, fifteen to twenty feet or more a season. Ripens latter part of August. Fruits after Concord Concord _-

Diamond -

Moore's Early _-_-

Niagara

\section{RASPBERRY}

Cuthbert

Cumberland

St. Regis or Ranere

We can furnish St. Regis Raspberry in carload lots. Ask for prices. 100 acres of Certified Mosaic free stock.

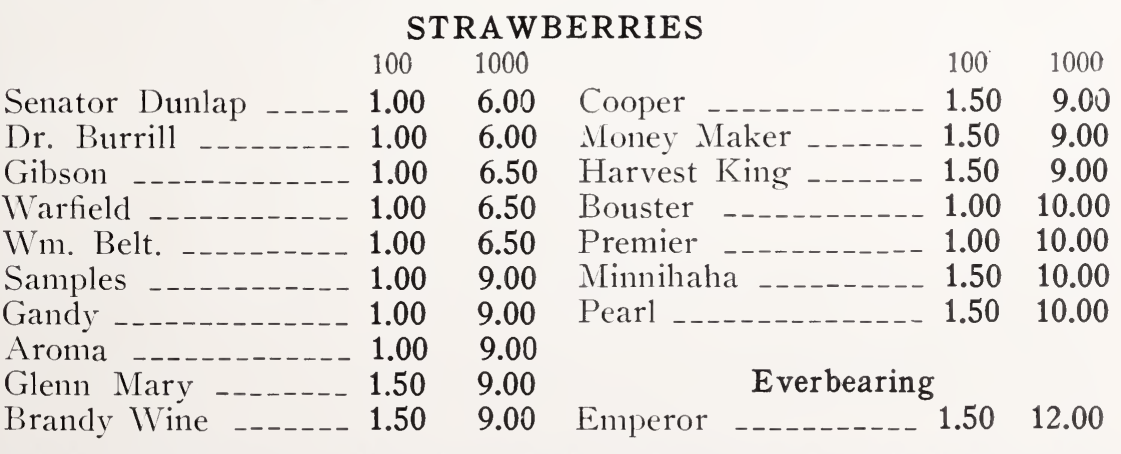


SHADY LAWN NURSERIES : Hugo Kind : HAMMONTON, N. J.

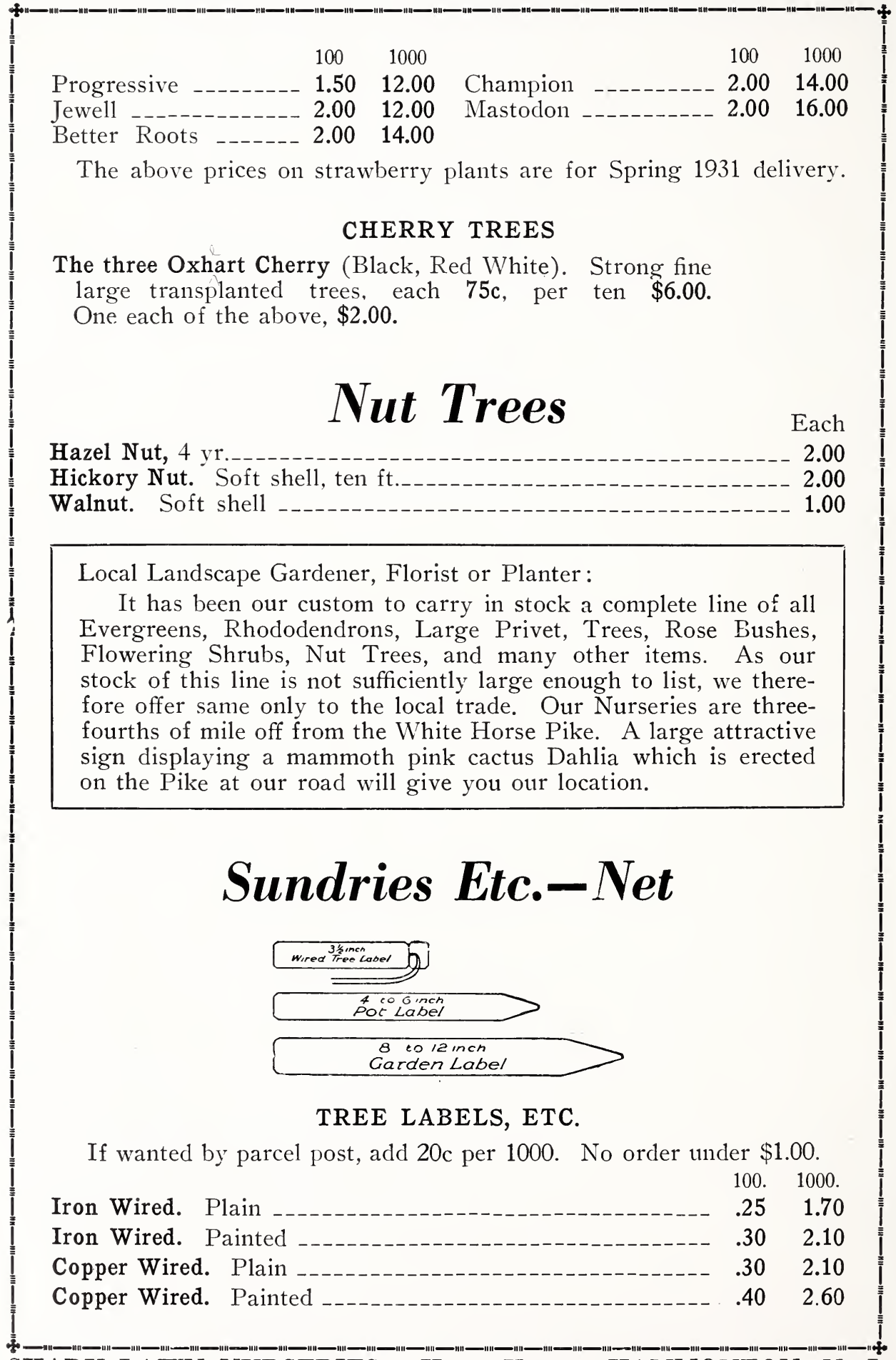

SHADY LAWN NURSERIES : Hugo KIND : HAMMONTON, N. J. 
SHADY LAWN NURSERIES : Hugo KIND : HAMMONTON, N. J.

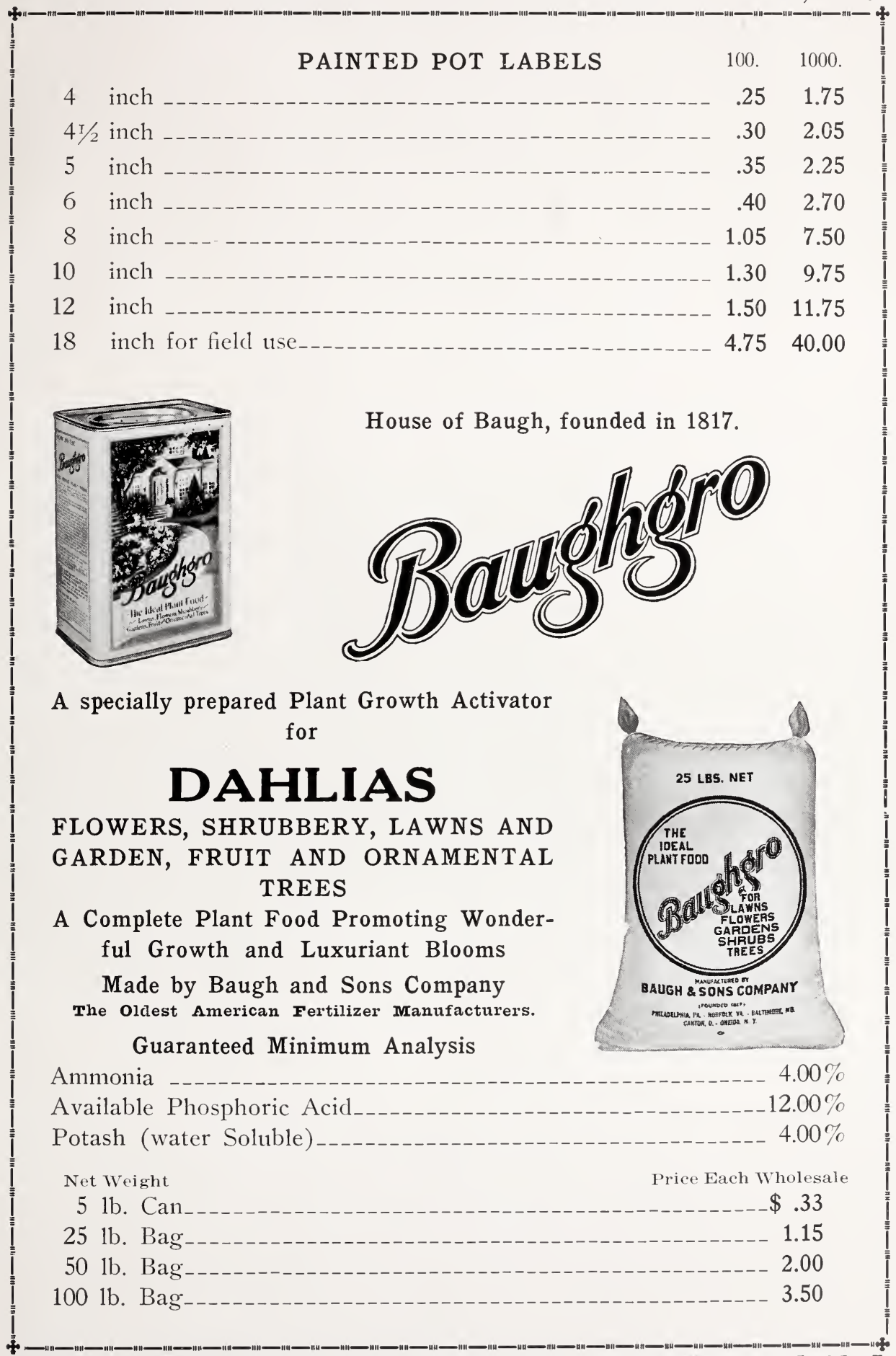

SHADY LAWN NURSERIES : Hugo KIND : HAMMONTON, N. J. 
SHADY LAWN NURSERIES : Hugo Kind : HAMMONTON, N. J.

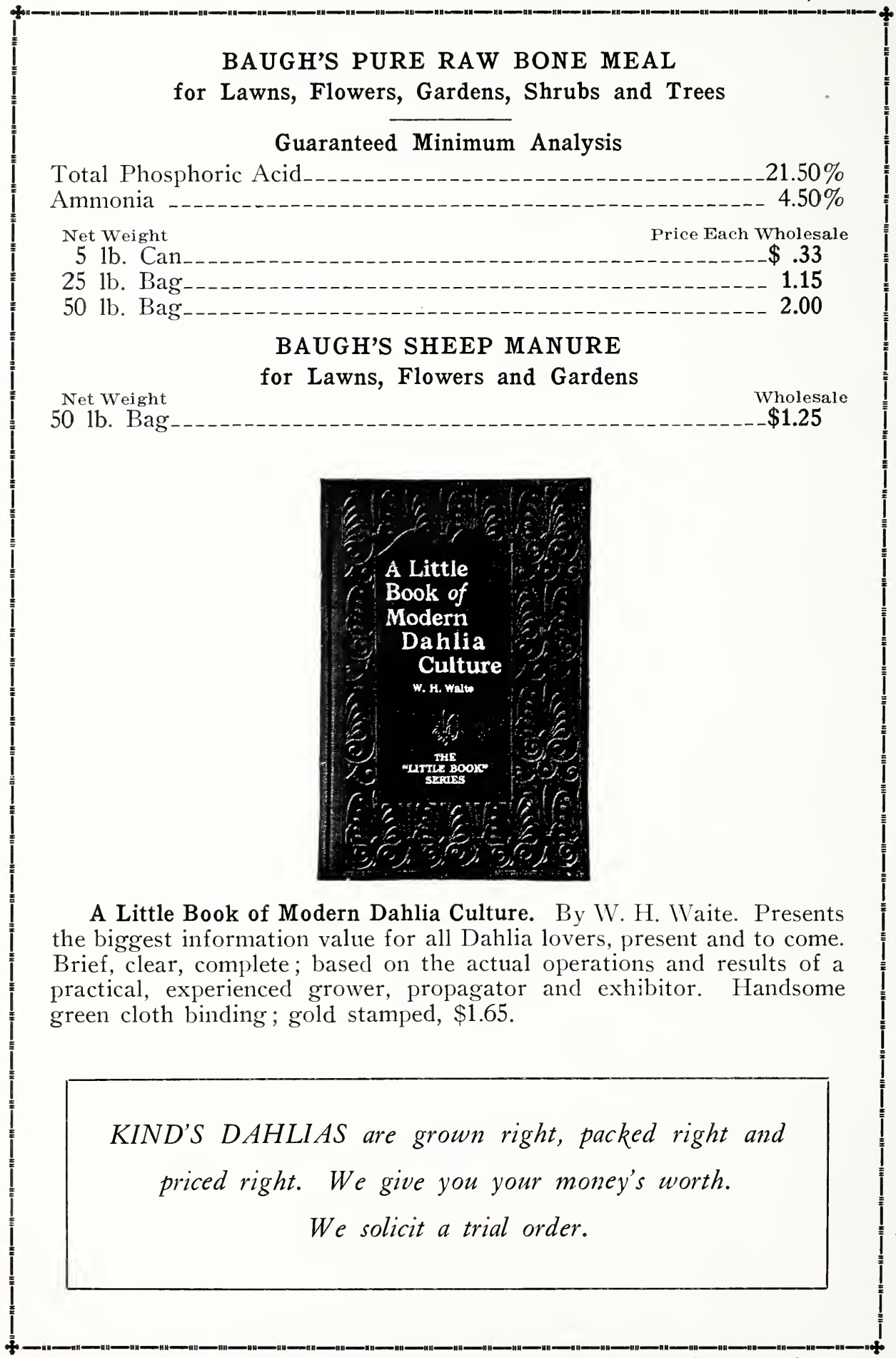




\section{SHADY LAWN NURSERIES}

\section{Hugo Kind}

Phone 440

Date

State here whether you want shipment to

be made by Mail, Express or Freight

Name

When Ship

Street Address or Box No.

Post Office

County

R. D. Route

State

If different from Post Office give

name of Express or Freight Offlce

Quantity




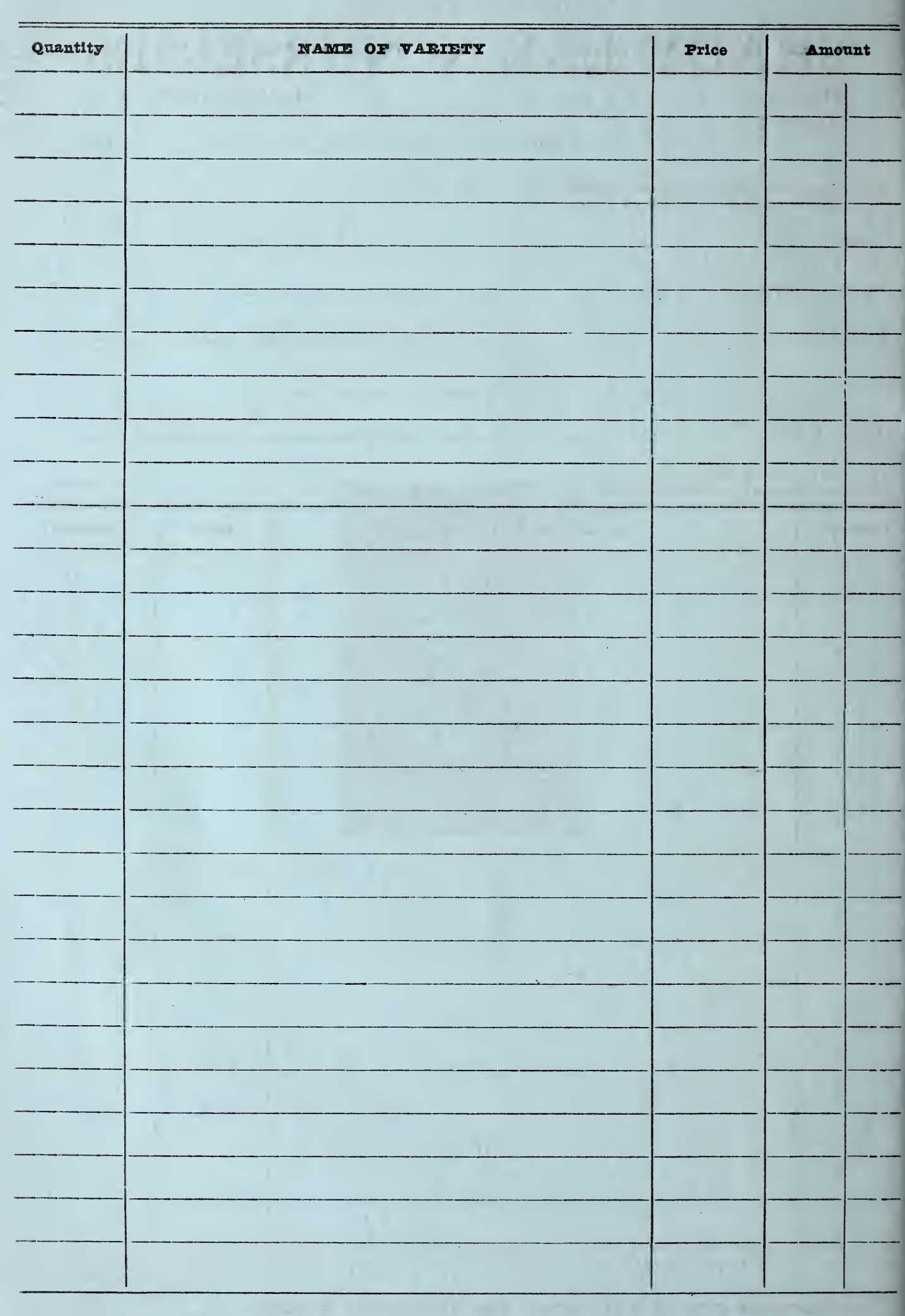




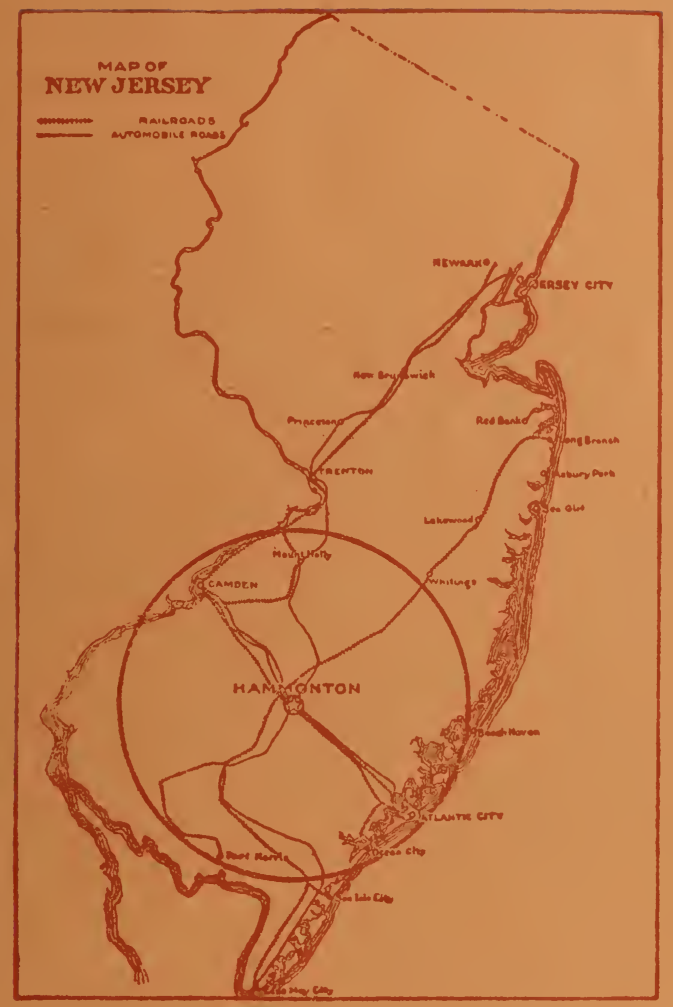




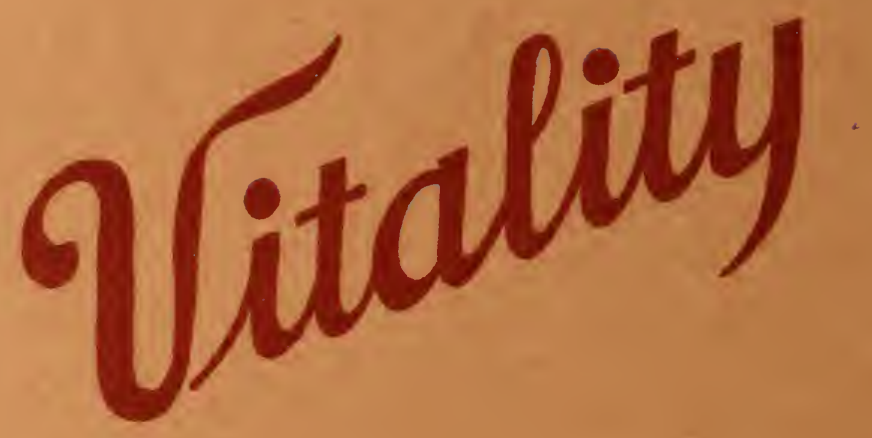

